\title{
Shallow magmatic processes revealed by cryptic microantecrysts: a case study from the Taupo Volcanic Zone
}

\author{
Charline Lormand ${ }^{1}$ (1) - Georg Florian Zellmer ${ }^{2} \cdot$ Naoya Sakamoto $^{3} \cdot$ Teresa Ubide $^{4} \cdot$ Geoff Kilgour $^{5}$. \\ Hisayoshi Yurimoto ${ }^{3} \cdot$ Alan Palmer $^{6} \cdot$ Karoly Németh $^{2} \cdot$ Yoshiyuki lizuka $^{7} \cdot$ Anja Moebis $^{6}$
}

Received: 31 July 2021 / Accepted: 18 October 2021 / Published online: 5 November 2021

(c) Crown 2021

\begin{abstract}
Arc magmas typically contain phenocrysts with complex zoning and diverse growth histories. Microlites highlight the same level of intracrystalline variations but require nanoscale resolution which is globally less available. The southern Taupo Volcanic Zone (TVZ), New Zealand, has produced a wide range of explosive eruptions yielding glassy microlite-bearing tephras. Major oxide analyses and textural information reveal that microlite rims are commonly out of equilibrium with the surrounding glass. We mapped microlites and microcrysts at submicron resolution for major and trace element distributions and observed three plagioclase textural patterns: (1) resorption and overgrowth, (2) oscillatory zoning, and (3) normal (sharp) zoning. Pyroxene textures are diverse: (1) resorption and overgrowth, (2) calcium-rich bands, (3) hollow textures, (4) oscillatory zoning, (5) sector zoning, (6) normal zoning and (7) reverse zoning. Microlite chemistry and textures inform processes operating during pre-eruptive magma ascent. They indicate a plumbing system periodically intruded by shortlived sub-aphyric dykes that entrain microantecrysts grown under diverse physico-chemical conditions and stored in rapidly cooled, previously intruded dykes. Changes in temperature gradients between the intrusion and the host rock throughout ascent and repeated magma injections lead to fluctuations in cooling rates and generate local heterogeneities illustrated by the microlite textures and rim compositions. Late-stage degassing occurs at water saturation, forming thin calcic microcryst rims through local partitioning effects. This detailed investigation of textures cryptic to conventional imaging shows that a significant proportion of the micrometre-sized crystal cargo of the TVZ is of antecrystic origin and may not be attributed to late-stage nucleation and growth at the onset of volcanic eruptions, as typically presumed.
\end{abstract}

Keywords Microcrysts $\cdot$ Tongariro volcanic centre $\cdot$ Chemical zoning $\cdot$ Intermediate magmas $\cdot$ Magma ascent

\section{Introduction}

\section{Linking volcanism to crystal magmatic processes}

To better understand the processes driving volcanic unrest, geophysical and geochemical tools as well as field observations are used to investigate magmatic systems beneath

Communicated by Othmar Müntener.

Charline Lormand

charline.lormand@durham.ac.uk

1 Department of Earth Sciences, Durham University, Durham, UK

2 School of Agriculture and Environment, Volcanic Risk Solutions, Massey University, PO Box 11222, Palmerston North 4442, New Zealand

3 Isotope Imaging Laboratory, Natural History Sciences, Hokkaido University, Sapporo 060-0810, Japan
4 School of Earth and Environmental Sciences, The University of Queensland, Brisbane, QLD 4072, Australia

5 GNS Science, Wairakei Research Centre, Private Bag 2000, Taupo 3352, New Zealand

6 School of Agriculture and Environment, Department of Soil Science, Massey University, PO Box 11222, Palmerston North 4442, New Zealand

7 Institute of Earth Sciences, Academia Sinica, 128 Academia Road Sec. 2, Nankang, Taipei 11529, Taiwan 
active volcanoes. Volcano monitoring employs a wide range of techniques with an array of data streams, including deformation (e.g. Nakao et al. 2013), remote sensing (e.g. Meyer et al. 2015) and seismicity (e.g. Kim et al. 2018). Real-time data are interpreted in the context of magmatic processes and eruptive behaviour recorded in past eruptive products, through petrological descriptions (e.g. Jerram et al. 2018), melt inclusion analyses (e.g. Kilgour et al. 2013), isotopic investigations (e.g. Sosa-Ceballos et al. 2014), and interpretation of deposits (e.g. Donoghue et al. 1995). For instance, magma mixing, regarded as a frequent eruption trigger (e.g. Sparks et al. 1977), is commonly inferred from a wide range of methodologies and can be observed at different scales through detailed petrological analyses; indeed, first observed in hand specimen of rocks as a sharp contact between two magma types, i.e. mingling (e.g. Walker and Skelhorn 1966), magma mixing is also observed at the crystal scale (e.g. Schleider et al. 2016). In addition to mixing events, mineral textures and compositions record changes in pressure and temperature prior to eruption (e.g. Cashman and Blundy 2013; Putirka 2008; e.g. Sparks et al. 1977), which help to understand the physico-chemical processes that govern eruption triggering. This in turn, can be used for volcanic hazard assessment.

Many models of magmatic plumbing systems have been presented to explain the complexity of crystal cargoes. A single magma reservoir (e.g. Costa et al. 2009; Wilson et al. 2003), layered magma chambers (e.g. Civetta et al. 1991; Humler and Whitechurch 1988), and multiple interconnected small storage regions (e.g. Hobden et al. 1999; Longpré et al. 2009; Ubide and Kamber 2018) have all been envisioned as potential plumbing system architectures. Within a single pyroclast or lava fragment, crystal cargoes are often composed of multiple crystal textures with differing histories and ages. Such diversity has led to the identification of longlived (e.g. $10^{5}$ years) crystal mush zones (e.g. Bragagni et al. 2014; Jerram and Martin 2008; Martin et al. 2006). The mush model contends that the magma reservoir consists of a crystal-rich framework with small volumes of interstitial melt, where crystals accumulate and continue to grow and diffusively equilibrate (e.g. Allan et al. 2013; Bachmann and Bergantz 2004, 2006; Costa et al. 2010; Nakamura 1995). Crystals may form in different intrusions and may develop various textures depending on their local environment and location within the crystal mush body. Because of their high packing fractions, crystal mushes are difficult to mobilise (Marsh 1981). However, mush fragments can be erupted when entrained by a percolating magma batch, moving upwards towards shallower levels and eventually reaching the surface upon eruption (Cashman et al. 2017). Hence, crystals that reach the surface provide a partial but rich window into the textures that can develop within magma reservoirs at depth.

\section{Crystal textures}

Crystals record the magmatic processes and the history of the magmas in which they grew (Agostini et al. 2013; Allan et al. 2013) and, thus, provide essential insights on crystallisation kinetics and conditions. From their storage to eruption, crystal zonations may reflect intrusion of a compositionally distinct magma (Sparks et al. 1977; Ubide and Kamber 2018), pressure and temperature conditions (Berlo et al. 2007; Coote and Shane 2016; Nelson and Montana 1992), cooling rate (e.g. Mollo et al. 2011a, b; Pankhurst et al. 2018), degree of degassing (e.g. Cashman and Blundy 2000; Giacomoni et al. 2014; Renjith 2014), late-stage volatile saturation (e.g. Klügel et al. 2020; Zellmer et al. 2015), and initial conditions of magma ascent and associated growth kinetics (i.e. degree of undercooling; Lasaga 1982; Muncill and Lasaga 1988; Sparks 1978).

Disequilibrium textures such as resorption are common in volcanic crystals and have previously been attributed to pressure and temperature fluctuations (e.g. Cashman and Blundy 2000; Nelson and Montana 1992), magma mixing/ recharge (e.g. Agostini et al. 2013; Bennett et al. 2019a, b; Shane et al. 2017; Tost et al. 2016), and associated recycling of old crystals (e.g. Armienti et al. 2007). Oscillatory zoning has been linked to fluctuations of the intensive parameters in the magma reservoir such as pressure and temperature (e.g. Cashman and Blundy 2000). Other causes such as temporal variations in the melt compositions (e.g. Ubide et al. 2019a, b), variations in growth rate (e.g. Halden and Hawthorne 1993) and diffusion-induced chemical gradients between the melt and the mineral (e.g. Grove et al. 1984) have also been suggested to explain oscillatory zoning.

High-resolution investigations of microtextures can unravel the processes occurring at shallower depth in the leadup to eruption. For instance, recent studies focusing on crystal size distribution and numerical conduit model using microlites and microcrysts (Arzilli et al. 2019; Lormand et al. 2020; Moschini et al. 2021) have contributed to our understanding of crystallisation kinetics during magma ascent in the conduit which revealed the links between undercooling and magma ascent rates. Although studies about microphenocryst compositional changes and textures have been reported since the late 1980s (e.g. Cashman 1988; Hammer et al. 1999, 2000; Hammer and Rutherford 2002), image resolution of analytical instruments allows us, more than ever, to visualise and quantify chemical variations down to submicron scale. Hence, this study uses well-contrasted BSE images and detailed microchemical analyses to highlight intracrystalline changes in the smallest crystals testifying to complex magma dynamics 
at shallow depths. In the following, we use the crystal size terminology of Zellmer (2021), where the shortest axis of microlites is $<30 \mu \mathrm{m}$, and wider crystals are divided on basis of their longest axis into microcrysts $(<100 \mu \mathrm{m}$ in length) and mesocrysts ( $\geq 100 \mu \mathrm{m}$ but $<500 \mu \mathrm{m}$ in length, which is the upper limit of microphenocrysts as defined by MacKenzie et al. 1982).

\section{Origin of microlites and microphenocrysts}

The increasing resolution of geochemical imaging has allowed the observation of ever smaller-scale heterogeneities. Microlites and microcrysts are believed to be associated with late-stage crystallisation upon magma ascent and eruption (e.g. Jerram et al. 2018; Noguchi et al. 2006; Shane et al. 2017) and are not often investigated when looking at the origin of the crystal cargoes of volcanic rocks. Several recent studies, however, have used their textures and morphology to gain insights into eruption dynamics (e.g. Martel 2012), the factors controlling eruption style (e.g. Lormand et al. 2020), and to get a better understanding of degassing and crustal processes (e.g. Noguchi et al. 2006).

In this study, we focus on the textural features of selected microlites to mesocrysts erupted in andesitic tephras from vents in the Tongariro Volcanic Centre ( $\mathrm{TgVC}$ ), which were recently subject to size characterisation (Lormand et al. 2018) and CSD analysis (Lormand et al. 2020). Crystal textures are used to explore the response of crystal cargo to the final stages of magma ascent, degassing and eruption in this active volcanic arc. Indeed, $\mathrm{TgVC}$ has produced a wide range of eruption sizes and styles (i.e. Strombolian, Vulcanian, sub-Plinian, Plinian, phreatic and phreatomagmatic) yielding glassy and microlite-rich juvenile shards. For the intermediate magmas of $\mathrm{TgVC}$, we will show that mesocrysts, microcrysts and even some of the microlites display complex zonations and textures, sometimes only visible when applying high-resolution elemental analysis (i.e. Stacked-CMOS-Active-Pixel-Sensor-equipped SIMS referred to here as simply SCAPS). We then use these data to infer magma architecture beneath the $\mathrm{TgVC}$ and importantly show that a significant portion of small crystals (microlites and microcrysts) have an antecrystic origin (cf. genetic classification of Zellmer 2021). Based on this work, we suggest that a reappraisal of the petrogenetic processes at play in the subvolcanic crust beneath $\mathrm{TgVC}$, and possibly at other arc volcanic centres globally, may utilise micrometer-sized crystals to assess fundamental magmatic processes.

\section{Geological setting}

The Tongariro Volcanic Centre (TgVC, Cole 1978) is the most frequently active volcanic centre of the Taupo Volcanic Zone, located in the North Island of New Zealand (Fig. 1).
The TVZ is undergoing extension and clockwise rotation due to the oblique subduction of the Pacific Plate beneath the Zealandia continent (Mortimer 2004). The TgVC is composed of two volcanic centres - Ruapehu and Tongariroand over 30 volcanic vents including the Ngauruhoe volcanic cone (Fig. 1). Over the past 26,000 years, the TgVC has produced Strombolian to Plinian eruptions, providing a wide range of eruptive products. The westerly prevailing winds have led to a well-preserved and well-exposed stratigraphy of tephras from these eruptions along an eastern ring plain (e.g. Donoghue et al. 1995).

Previous studies of the TgVC have revealed different eruptive scenarios and magmatic processes based on the petrology of historical deposits. Several studies have described disequilibrium textures of phenocrysts, including sieve-textured plagioclases resulting from mixing and/or rapid decompression of magma (Shane et al. 2019); indeed, sieve textures were observed in Pukeonake lavas (Beier et al. 2017; Shane et al. 2019), Ngauruhoe lavas, Ruapehu andesite-hosted rhyolitic xenoliths (Price et al. 2005), Ruapehu andesites (Donoghue et al. 1997), Ruapehu-sourced mass flow deposits (Tost et al. 2016), and Red Crater lavas (Shane et al. 2017). Oscillatory zoning is also commonly found in many TgVC andesites (Cole 1978), including in plagioclase phenocrysts of Pukeonake lavas (Beier et al. 2017), Ngauruhoe lavas (Coote and Shane 2016), Tufa Trig tephras (Donoghue et al. 1997) and Red Crater lavas (Shane et al. 2017). In fact, plagioclase phenocrysts from Red Crater display diverse textures and compositional growth patterns such as resorption, oscillatory zoning, and sieve textures, suggesting a reservoir, either crystal- or melt-dominated, where crystals of differing ages and histories coexist before being erupted. Furthermore, resorbed crystals/cores with oscillatory-zoned mantles have been described in the $\mathrm{TgVC}$ as part of the 1996 deposits of Mt. Ruapehu (Kilgour et al. 2014), the Ngauruhoe Formation (Coote and Shane 2016), the Red Crater lavas (Shane et al. 2017), the 27-11 cal. ka BP Bullot Formation from Ruapehu (Pardo et al. 2014), and the 26-16.6 ka BP pyroclastic deposits from Mt. Tongariro (Shane et al. 2007).

Despite their volcanological interest, microlite and microcryst textures of TgVC products have remained poorly studied. Previously described as groundmass crystals which appear featureless using traditional petrography and scanning electron microscope imaging (e.g. in Red Crater lavas; Shane et al. 2017), microlites and microcrysts from volcanic tephras, quenched at the onset of the eruptions, may provide rich insights into the subvolcanic plumbing system when observed with novel, high-resolution imaging techniques, as explored here. 


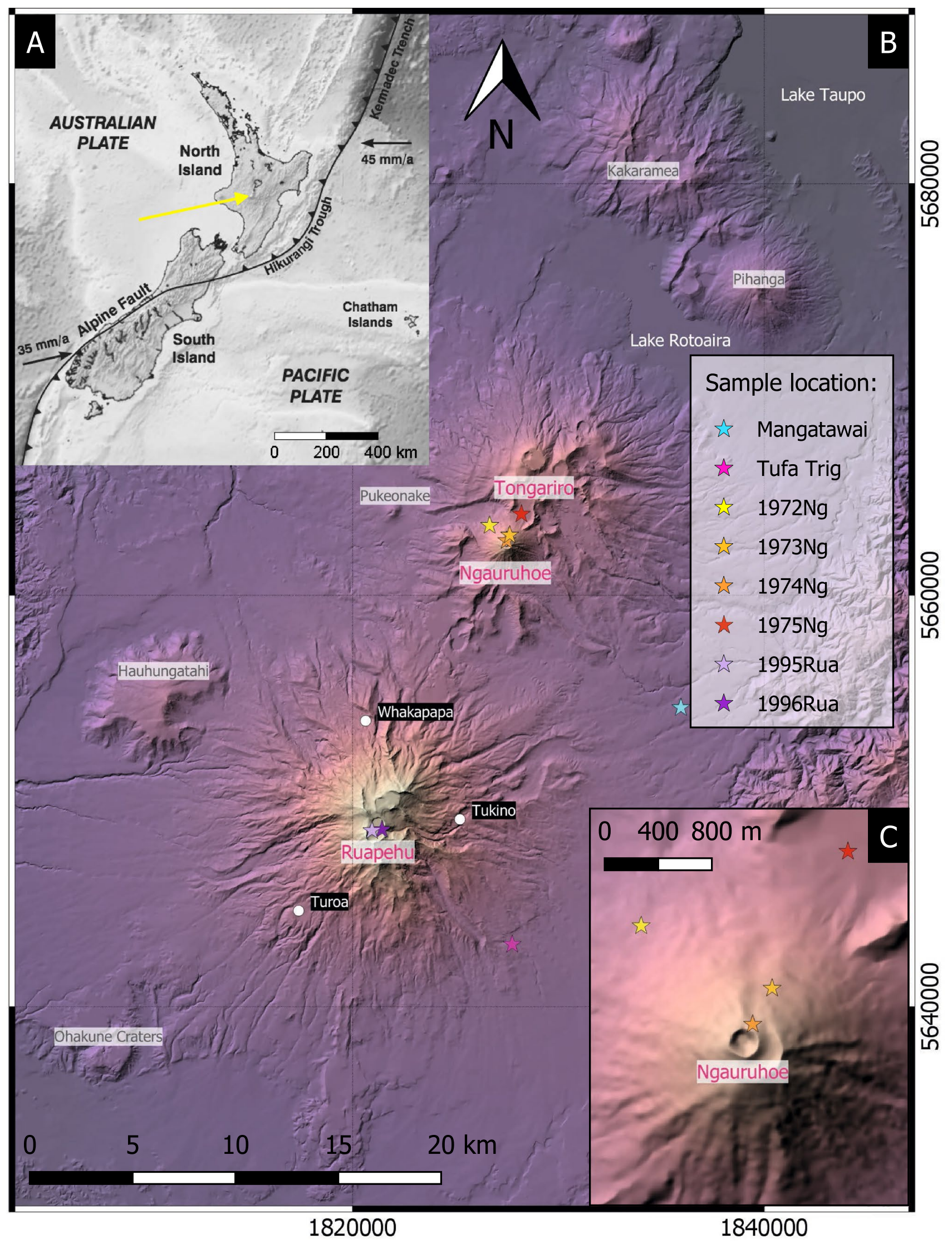


4Fig. 1 A Map of the current tectonic setting in New Zealand illustrated by the subduction of the Pacific Plate beneath the Australian Plate ( source: GNS Science). The location of the Tongariro Volcanic Centre (TgVC) is indicated by the yellow arrow. B Map of the locations of the recently active volcanoes (Tongariro, Ngauruhoe and Ruapehu) and volcanic vents (Te Maari, Red Crater, Tama Lakes and Saddle Cone), the inactive/extinct volcanoes (Kakaramea, Pihanga, Pukeonake, Hauhungatahi and Ohakune Craters), the ski fields (Whakapapa, Tukino and Turoa), and the lakes (Rotoaira and Taupo) at TgVC. The shaded relief map is derived from the 8-m-Digital-Elevation-Model (source: LINZ data). The colour gradient corresponds to the elevation variation. Georeference system: NZGD2000/New Zealand Transverse Mercator 2000

\section{Analytical methods}

\section{Tephra selection and sample preparation}

Four tephra formations were selected from $\mathrm{TgVC}$, ranging from 3,500 years BP to 1996 and from Strombolian to subPlinian in style; (1) the 1.7-3.5 ka BP Strombolian to Vulcanian eruptions of the Mangatawai Formation (Donoghue et al. 1995), (2) the 0-1.7 ka BP Strombolian to sub-Plinian eruptions of the Tufa Trig Formation (i.e. Tf8, Tf13, Tf14, Tf15 and Tf16; Donoghue et al. 1997), (3) the 1972-1975 Strombolian to Vulcanian eruptions of the Ngauruhoe Formations, and the (4) 1995-1996 Ruapehu sub-Plinian eruptions (i.e. referred here as Rua95 and Rua96, also referred as Tf 19 in Auer et al. 2015). These deposits represent a broad range of eruption intensities and originate from different vents of the Tongariro Volcanic Centre. Tephra samples were sieved wet and dried in the oven. Glass shards ranging between $500 \mu \mathrm{m}$ and $250 \mu \mathrm{m}$ in diameter were handpicked and mounted into epoxy plugs. Microlites and microcrysts for all these tephras are mostly plagioclases and pyroxenes (typically orthopyroxene, with subordinate clinopyroxene and/or pigeonite).

\section{Mineral and glass major element analysis and tests for equilibrium}

Major element compositions of microlites, microcrysts and groundmass glass were analysed to assess equilibrium between the melts and the minerals (Supplementary Tables). Mangatawai and Tufa Trig tephras were analysed at the Institute of Earth Sciences, Academia Sinica, Taipei, Taiwan, using a JEOL JXA-8900R electron microprobe equipped with four wavelength-dispersive spectrometers. These analyses were performed with an acceleration voltage of $15 \mathrm{kV}$ and a 2- $\mu \mathrm{m}$-defocused beam with a current of $12 \mathrm{nA}$. Tephras from the 1972-1975 Ngauruhoe and the 1995-1996 Ruapehu eruptions were analysed at the Graduate School of Science, Hokkaido University, Sapporo, Japan, using a JEOL JXA-8800R electron microprobe equipped with four wavelength-dispersive spectrometers. The analyses were performed using an accelerating voltage of $15 \mathrm{kV}$ and a $10-\mu \mathrm{m}$-defocused beam with a current of $7 \mathrm{nA}$ for glass, whereas the mineral analyses were performed using a fully focused beam with a current of $10 \mathrm{nA}$ for plagioclases and $20 \mathrm{nA}$ for pyroxenes. Plagioclase-liquid equilibrium was assessed based on the experimental calibration of the plagioclase hygrometer of Waters and Lange (2015) following the method in Lormand et al. (2020), which calculated melt $\mathrm{H}_{2} \mathrm{O}$ content and temperature iteratively using the P-T-dependent plagioclase hygrometry (Waters and Lange, 2015), and the pyroxene-liquid thermobarometry, which, in turn, is affected by liquid $\mathrm{H}_{2} \mathrm{O}$ content (Putirka, 2008). Pyroxene-liquid equilibrium was assessed using the $\mathrm{Fe}-\mathrm{Mg}$ exchange coefficient determined by Putirka (2008) for both orthopyroxene $\left(\mathrm{Kd}(\mathrm{Fe}-\mathrm{Mg})^{\mathrm{opx}-\mathrm{liq}}=0.29 \pm 0.06\right)$ and clinopyroxene $\left(\mathrm{Kd}(\mathrm{Fe}-\mathrm{Mg})^{\mathrm{cpx}-\mathrm{liq}}=0.28 \pm 0.08\right)$. Although it is accepted to use these $\mathrm{Fe}-\mathrm{Mg}$ exchange coefficients, which are the most common test for equilibrium, it is noteworthy to mention that they are the weighted arithmetic means of broad equilibrium ranges, e.g. $0.28+/-0.08$ for clinopyroxene, and they thus represent an approximation.

\section{Pyroclast imaging}

\section{Scanning electron microscopy (SEM)}

Back-scattered electron (BSE) images were obtained for pyroclasts from all the tephras (see examples in Fig. 2) using (1) the Field Emission Scanning Electron Microscope (FESEM; JEOL JSM-7000F) of the Isotope Imaging Laboratory (IIL) of Hokkaido University in Sapporo, Japan; (2) the Environmental-SEM (FEI Quanta 200) of Massey University in Palmerston North, New Zealand; or (3) the JEOL NEOSCOPE 6000plus desktop SEM of GNS Science Wairakei Research Centre in Taupo, New Zealand. BSE images were used to gain an overview of the sample textures and to select regions of interest for further imaging/analysis. At IIL, SEM elemental maps of pyroxene microlites to microcrysts were obtained for $\mathrm{Al}, \mathrm{Ca}, \mathrm{Cr}, \mathrm{Fe}, \mathrm{Mg}, \mathrm{Na}, \mathrm{K}, \mathrm{Si}$ and Ti.

\section{Secondary ion mass spectroscopy (SIMS)}

Semi-quantitative concentration maps for plagioclase crystals were obtained at ILL using a Cameca IMS-1270 SIMS instrument equipped with a Stacked CMOS-type Active Pixel Sensor (SCAPS). Preferred sites for SCAPS imaging were those containing euhedral crystals or crystals with observed zonations/shading in BSE. This microscope system is applied to visualise the elemental distribution on the sample surface at high magnification (i.e. isotopography, Yurimoto et al. 2003) for Al, Ca, Fe, Mg, Na, K, Si. 


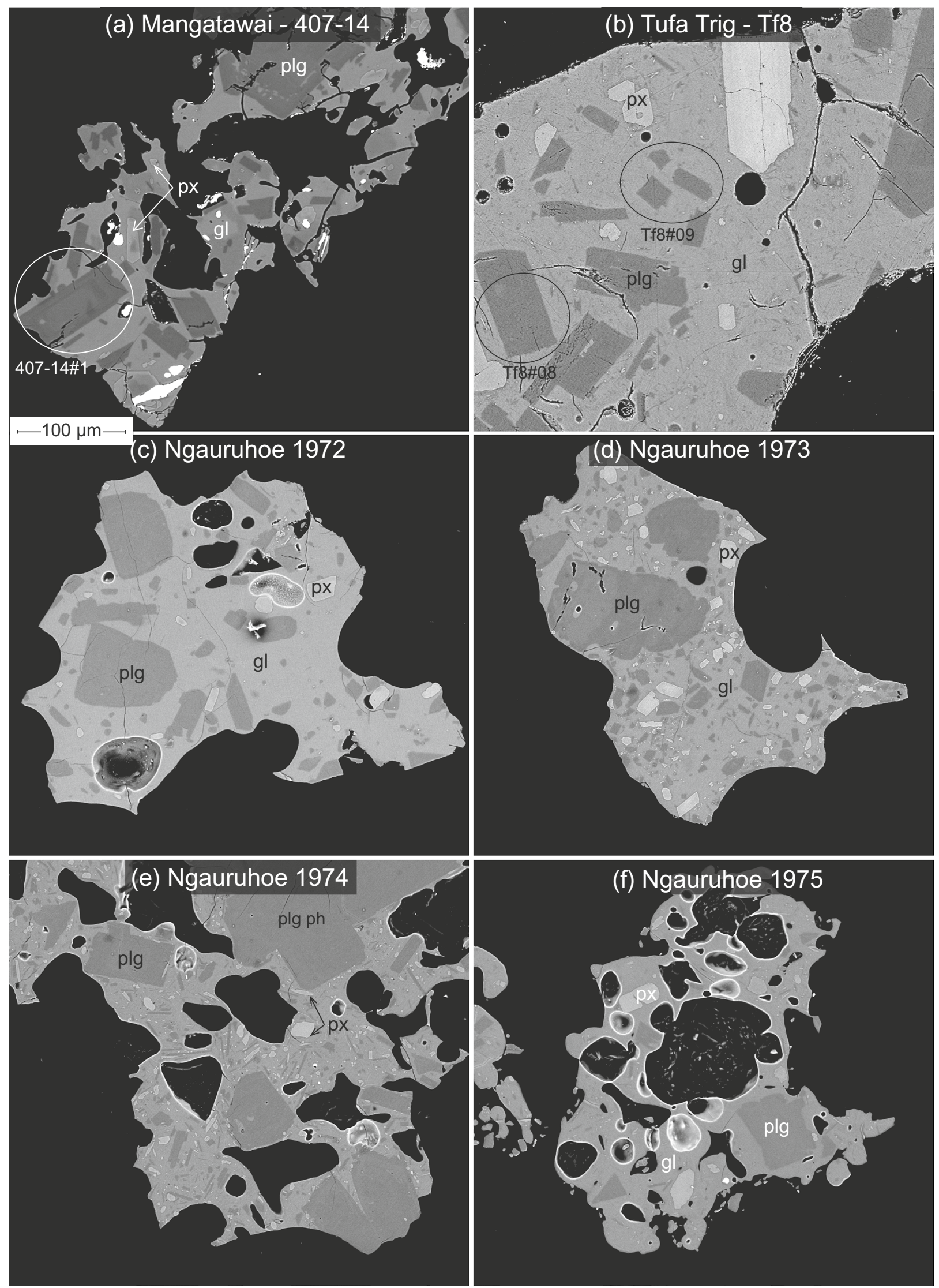


4Fig. 2 Typical back-scattered electron images of the tephras from the TgVC of this study: Mangatawai, Tufa Trig, and Ngauruhoe 1972, 1973, 1974 and 1975. Mangatawai and Tufa Trig images were captured using the Environmental-SEM (FEI Quanta 200) of Massey University in Palmerston North, New Zealand. Ngauruhoe images were captured using the JEOL NEOSCOPE 6000plus desktop SEM of GNS Science Wairakei Research Centre in Taupo, New Zealand. $\mathrm{Plg}, \mathrm{px}$, and gl stand for plagioclase, pyroxene and glass, respectively. The scale of $100 \mu \mathrm{m}$ is identical for all panels. Panels $\mathrm{c}$ and $\mathrm{d}$ are from Lormand et al. (2020)

An $\mathrm{O}^{-}$primary beam of $23 \mathrm{keV}$ was irradiated on the sample surface of $80-100 \mu \mathrm{m}$ in diameter using a $7 \mathrm{nA}$ beam current. The sample surface was sputtered with a $20 \mathrm{nA}$ beam current for ten minutes before the analysis. The positive secondary ion images of ${ }^{23} \mathrm{Na},{ }^{24} \mathrm{Mg},{ }^{27} \mathrm{Al},{ }^{28} \mathrm{Si},{ }^{39} \mathrm{~K}$, ${ }^{40} \mathrm{Ca}$, and ${ }^{56} \mathrm{Fe}$ on the sample surface were collected by the SCAPS detector, with exposure times of 50, 500, 50, 25, 50 and $250 \mathrm{~s}$, respectively. A submicron spatial resolution was achieved on individual images. Concentration ratio images normalised to Si were used to discriminate elemental zoning and textures of plagioclase microlites to mesocrysts.

\section{Crystal texture classification}

Thirty-seven images of plagioclase and pyroxene microlites and microcrysts were acquired using SCAPS and SEM elemental imaging, respectively. The images were used to define textural types of plagioclase (one texture and 2 types of zonations on 22 images) and pyroxene (three textures and 5 types of zonations on 15 images), where a given crystal often displays more than one feature.

\section{Results}

\section{Major element chemistry}

Microprobe analyses demonstrate that glasses $(n=127$; see Supplementary Table 1) from Mangatawai $(n=70)$, Tufa Trig $(n=32)$, Ngauruhoe $(n=19)$ and Ruapehu $(n=6)$ tephras are compositionally intermediate with $65 \%$ being andesitic, 33\% dacitic and 2\% basaltic-andesitic (Fig. 3a).

Microprobe analyses on plagioclases $(n=529$; see Supplementary Table 2) from Mangatawai $(n=327)$, Tufa Trig $(n=181)$, Ngauruhoe $(n=21)$ and Ruapehu $(n=6)$ consist of a main population (i.e. $~ 80 \%$ ) of bytownites, and two smaller populations of labradorites and anorthites (i.e. $\sim 13 \%$ and $\sim 7 \%$, respectively; see Fig. 3b). Plagioclase microlites and microcrysts have anorthite contents of $\mathrm{An}_{42-}{ }_{87}$ (Table 1). Specifically, anorthite contents decrease with time as the averages are $\mathrm{An}_{71}$ for Mangatawai Lower, $\mathrm{An}_{66}$ for Mangatawai Upper, $\mathrm{An}_{62}$ for Tufa Trig, $\mathrm{An}_{59}$ for Ngauruhoe 1972-1975 and $\mathrm{An}_{57}$ for Ruapehu 1995-1996.
Standard deviations of Mg\# and anorthite contents show that the range of these values can be large (see Table 1).

Microprobe analyses of pyroxenes ( $n=301$; see Supplementary Table 3$)$ from Mangatawai $(n=125)$, Tufa Trig ( $n=149)$, Ngauruhoe $(n=20)$ and Ruapehu $(n=7)$ tephras define a main population of orthopyroxenes (i.e. $\sim 66 \%$ of enstatite), a secondary population of pigeonites $(\sim 24 \%)$ and a smaller population of clinopyroxenes (i.e. $~ 7 \%$ augite and $\sim 2 \%$ diopside; see Fig. 3c). Orthopyroxene microlites and microcrysts have $\mathrm{Mg \#} \mathrm{ranging} \mathrm{from} 59$ (i.e. Ngauruhoe 1974) to 86 (i.e. Mangatawai; see Table 1). They have $\mathrm{Mg \#}$ averages of $73 \pm 7(1 \sigma), 73 \pm 3(1 \sigma), 71 \pm 6(1 \sigma), 73$ and $76 \pm 4(1 \sigma)$ for Mangatawai Lower, Mangatawai Upper, Tufa Trig, Ngauruhoe 1972-1975 and Ruapehu 1995-1996, respectively (Table 1 ). The clinopyroxenes have $\mathrm{Mg \#}$ averages of $80 \pm 4(1 \sigma), 74 \pm 2(1 \sigma), 75 \pm 5(1 \sigma), 64 \pm 4(1 \sigma)$ and $74 \pm 1(1 \sigma)$ for Mangatawai Lower, Mangatawai Upper, Tufa Trig, Ngauruhoe 1972-1975 and Ruapehu 1995-1996, respectively.

Among 266 orthopyroxene and 28 clinopyroxene microlite rims tested for equilibrium, $32(\sim 10 \%)$ and $11(\sim 40 \%)$ are in disequilibrium with their surrounding melt, respectively (Fig. 4). Among 504 plagioclases, $70 \%$ of the microlite rims are in equilibrium with their surrounding glass in the dry field (Table 2, Fig. 5), whereas $25 \%$ of the pairs are in equilibrium in the $\mathrm{H}_{2} \mathrm{O}$-saturated field (Waters and Langer 2015) and 5\% are out of equilibrium. Considering that $\mathrm{TgVC}$ magmas are $\mathrm{H}_{2} \mathrm{O}$-poor rather than $\mathrm{H}_{2} \mathrm{O}$-saturated (e.g. Kilgour et al. 2013; Lormand et al. 2020), disequilibrium is common, and it is, thus, essential to investigate the textures of small crystals using detailed imaging.

\section{Plagioclase textures and zonations}

\section{Resorption and overgrowth}

Resorption and overgrowth are the most common textures observed in plagioclase microlites and microcrysts (see Table 3). Two levels of resorption can be identified: some crystals are affected by limited resorption, while others show more complex, extended resorption. Crystals with limited resorption consist of a single resorption event characterised by a rounded anhedral core and continuous overgrowth of a euhedral to subhedral rim (Fig. 6a). Crystals with extended resorption have experienced several resorption events and show several rounded growth layers and a euhedral outer rim.

\section{Oscillatory zoning}

Oscillatory zonation is common, especially in the Tufa Trig tephras (see Table 3). Oscillatory zoned microlites and 

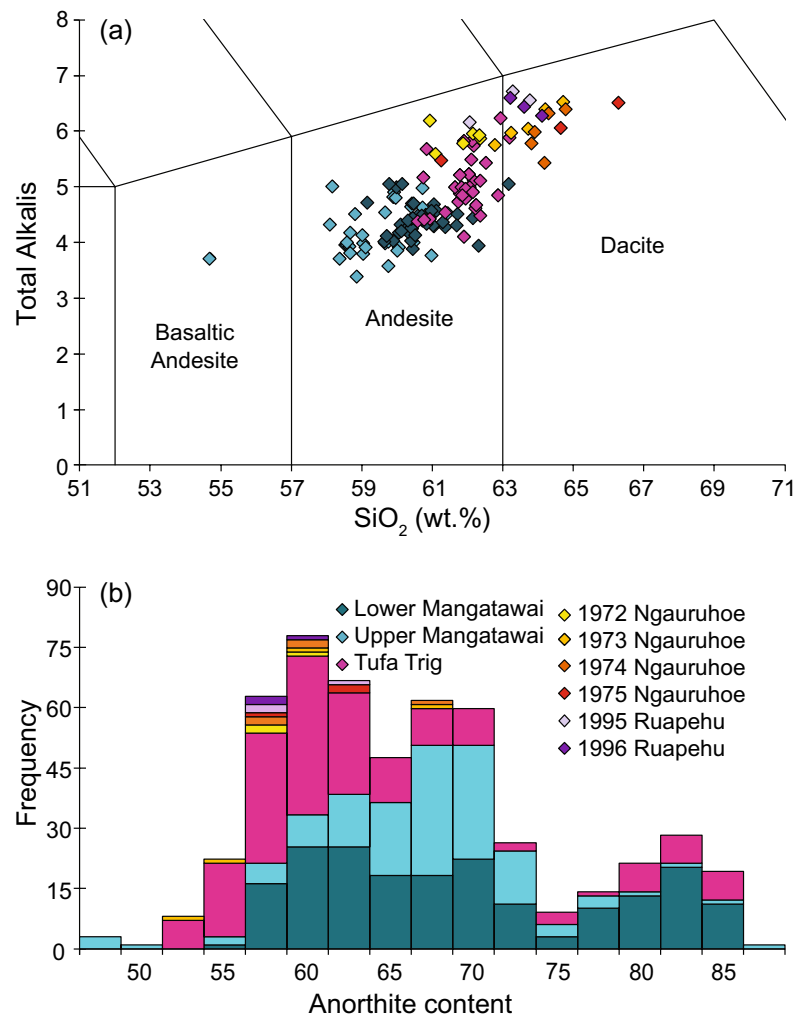

(c)

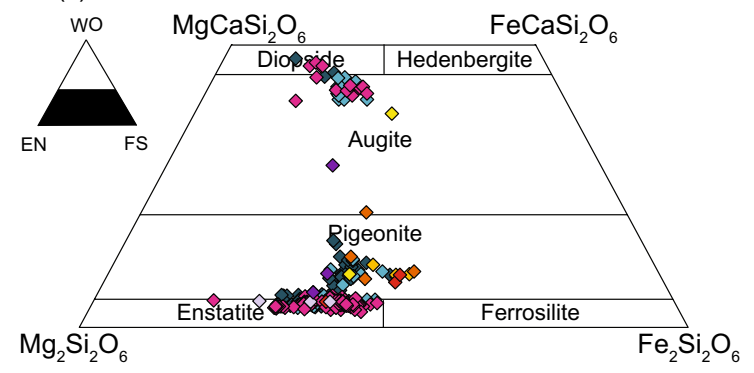

Fig. 3 Compositions of tephra glasses, microlites and microcrysts of TgVC: a TAS diagram for glasses (Le Bas et al. 1986), b histogram of anorthite contents of plagioclase rims and $\mathbf{c}$ discriminating chart for pyroxene rims (Morimoto, 1989). The crystal sizes of the mineral data only include microlites and microcrysts

microcrysts are characterised by various amplitudes and frequencies of compositional cycles of up to $30 \mu \mathrm{m}$ wide, usually parallel to crystal edges and with rounded corners (Fig. 6b). Most of the TgVC plagioclases have multiple thin $(1 \mu \mathrm{m}-10 \mathrm{~s}$ of $\mu \mathrm{m})$ oscillations. Commonly, plagioclase rim zones display oscillatory zoning and they mantle a wide unzoned core, which may be resorbed. In some crystals, resorption, fracturing or truncating of crystal edges may also have occurred. Besides, a few zoned crystals, ranging from $40 \mu \mathrm{m}$ to $\sim 100 \mu \mathrm{m}$ in length, display interrupted zoning where an oscillation may not be continuous (dotted lines in
Fig. $6 \mathrm{~b}$ and Supplementary Images Ib). Typically, fractures seem to follow the main cleavage planes of the crystal. Crystal cores appear rounded due to resorption before fracturing and crystal overgrowth.

\section{Normal (sharp) zoning}

Most of the crystals without oscillatory zoning are normally zoned with a steep concentration gradient defining the boundary between two growth zones (see Fig. $6 \mathrm{c}$ and Supplementary Images Ic). The growth zones can reach up to $20 \mu \mathrm{m}$ in width. About $50 \%$ of the crystals identified with this texture present a rounded calcic core, indicating that it may have undergone resorption before growth of the outer more sodic layer. This texture is the most common in the Mangatawai formation.

\section{Pyroxene textures and zonations}

\section{Resorption and overgrowth}

Resorption and overgrowth are commonly observed in pyroxenes, in tephras from Mangatawai, Tufa Trig and Ngauruhoe 1972-1975 (Table 3). Unlike the plagioclases, pyroxenes are less complex, smaller and typically have a resorbed rounded core with euhedral overgrowth (Fig. 7a and Supplementary Images IIa).

\section{Calcium-rich bands}

Commonly, pyroxenes also exhibit thin Ca-rich bands as parallel layers in basal cuts, identified based on crystal morphology (Krimer and Costa 2017; Ubide et al. 2019a, b; Table 3; Fig. 7b, and Supplementary Images IIb). In such cases, Ca-rich rims are also enriched in $\mathrm{Cr}, \mathrm{Fe}$, Ti but not in $\mathrm{Mg}$ (see Supplementary Images_all). The bands are usually thin and located at the rims $(\sim 1 \mu \mathrm{m}$ in width, e.g. Figure $7 \mathrm{~b}$, Supplementary Images), parallel to the (100) plane. However, in some rarer cases, they can be much thicker, appearing as entire sectors (Fig. 8b, e), and may be associated with parallel lines and/or a central compositional line (Fig. 8a, d), which are not as Ca-rich as the rim enrichments. Remarkably, these Ca-rich bands are not always continuous, especially in the cases where plagioclase microlites have crystallised close to the rim (Fig. 8a). These features are invisible in BSE (see Fig. 7b) and are observed in all three tephra formations (see Table 3). 


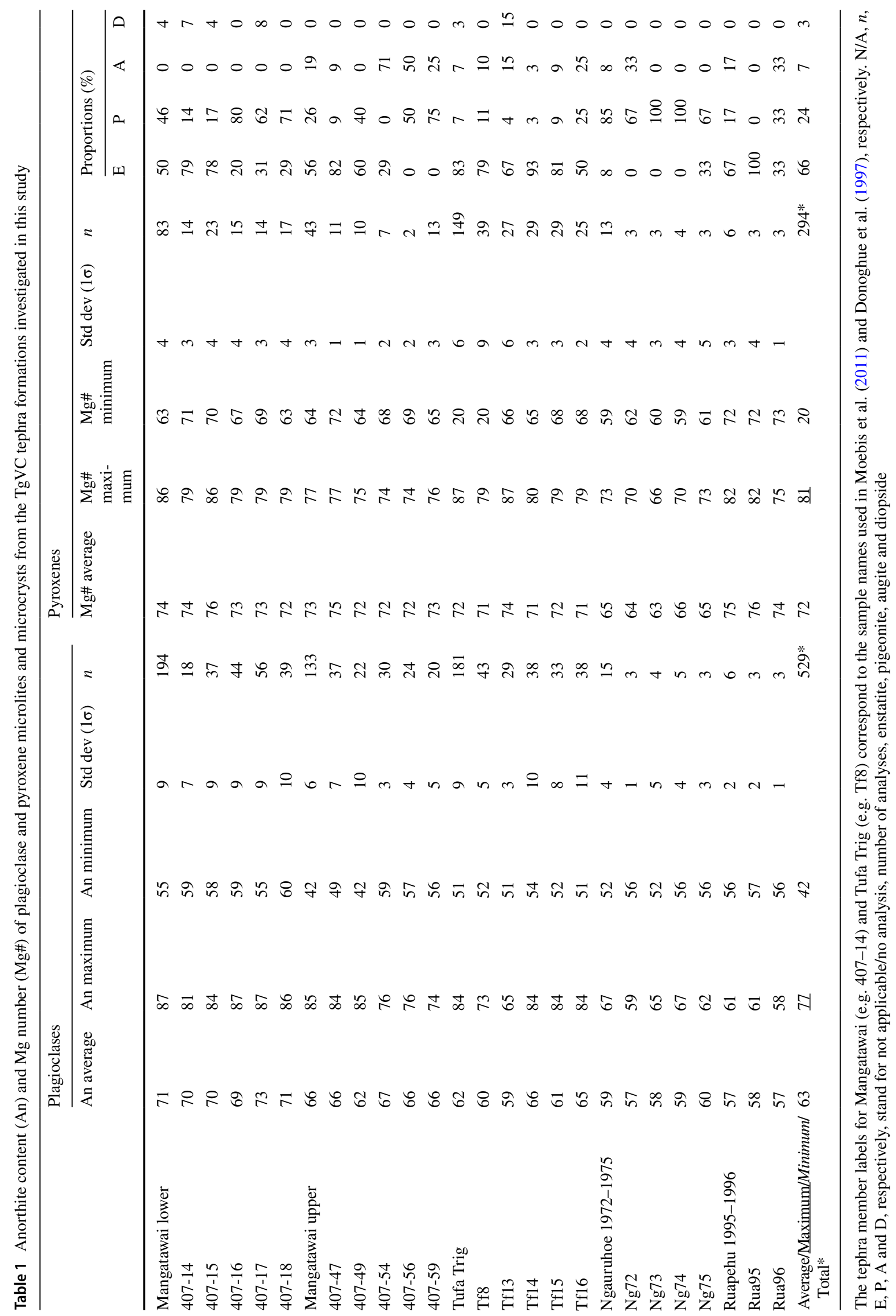




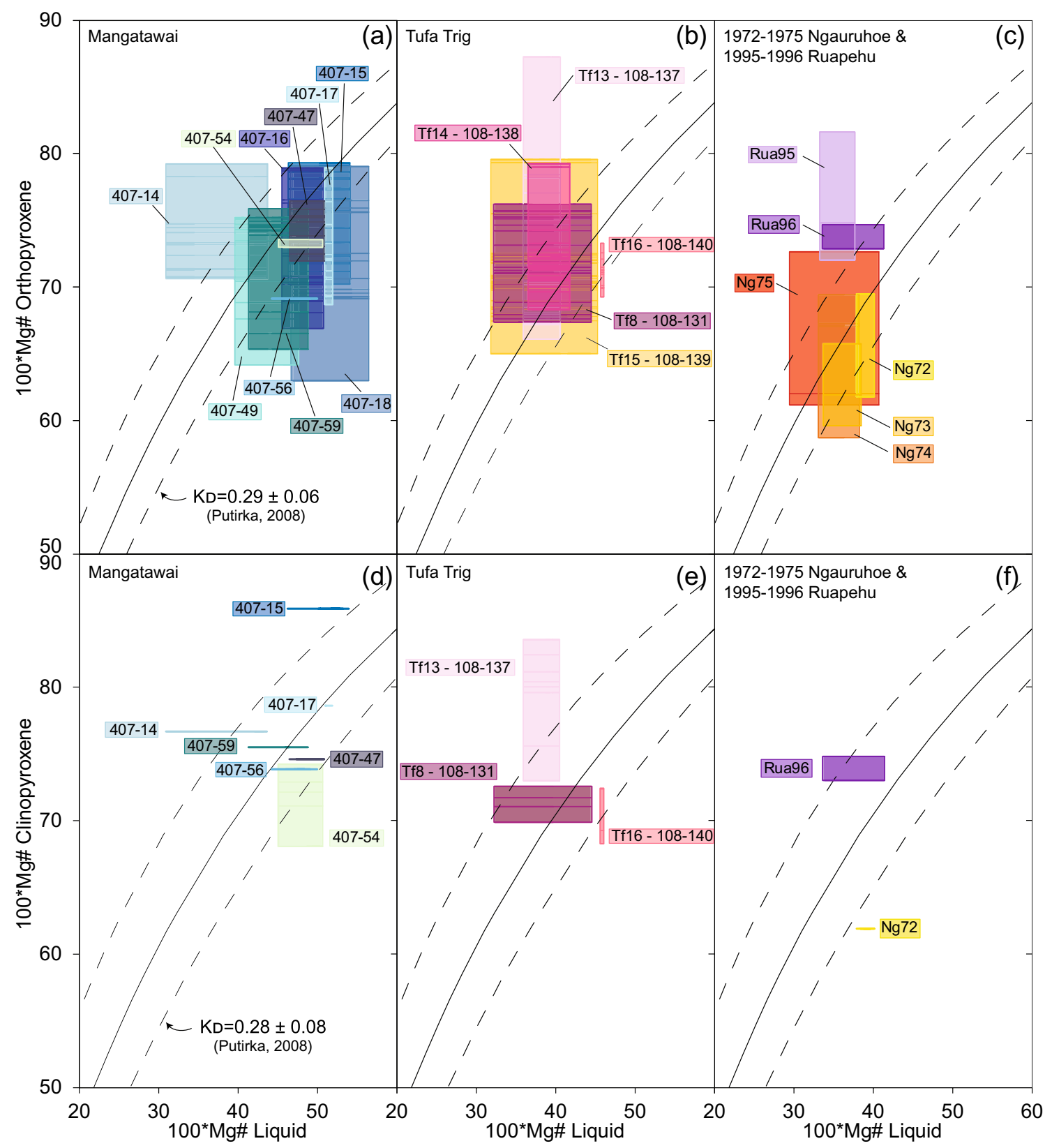

Fig. 4 Rhodes diagram to assess the equilibrium between the rims of pyroxene microlites and microcrysts from $\mathrm{TgVC}$ tephras and their surrounding glass. Each horizontal bar is a range in glass Mg\# hosting a single mineral grain. Orthopyroxene-liquid and clinopyroxene-

\section{Hollow textures}

Hollow textures in crystal cores suggest early hopper crystallisation. These voids filled with matrix glass may appear as elongated hollow formations in basal cuts (Fig. 7c), or as rounded void space in elongated cuts (see Fig. 8e). In some cases, hollow textures may be associated with a Carich compositional line (e.g. Figure 7c, see more examples in Supplementary Images IIc). This texture, which liquid equilibria were assessed using the $\mathrm{Fe}-\mathrm{Mg}$ exchange coefficients determined by Putirka (2008): $\mathrm{Kd}(\mathrm{Fe}-\mathrm{Mg})^{\text {opx }-\mathrm{liq}}=0.29 \pm 0.06$ and $\mathrm{Kd}(\mathrm{Fe}-\mathrm{Mg})^{\mathrm{cpx}-\mathrm{liq}}=0.28 \pm 0.08$. Note that disequilibrium is common, especially for the Mangatawai and Tufa Trig tephras

we interpret as remnant of early skeletal growth, is predominant in the Mangatawai tephras but is also observed in Tufa Trig.

\section{Oscillatory zoning}

Although less common than in the plagioclases, oscillatoryzoned pyroxenes are very frequent in all tephras studied here. The oscillations have distinct compositions in $\mathrm{Al}, \mathrm{Fe}$, 
Table 2 Proportion of the plagioclase-liquid pairs in the dry or/and $\mathrm{H}_{2} \mathrm{O}$-saturated conditions, which were determined experimentally by Waters and Langer (2015) for basaltic to rhyolitic melts

\begin{tabular}{|c|c|c|c|c|}
\hline \multirow[t]{2}{*}{ Sample } & \multicolumn{4}{|c|}{ Percentage of plagioclase-melt pairs in each field } \\
\hline & Dry & $\begin{array}{l}\text { Saturated } \\
\text { in } \mathrm{H}_{2} \mathrm{O}\end{array}$ & $\begin{array}{l}\text { Out of } \\
\text { equilibrium }\end{array}$ & Number of pairs \\
\hline $407-14$ & 0 & 100 & 0 & 18 \\
\hline $407-15$ & 67 & 33 & 0 & 39 \\
\hline $407-16$ & 59 & 34 & 7 & 44 \\
\hline $407-17$ & 57 & 31 & 12 & 58 \\
\hline $407-18$ & 59 & 41 & 0 & 37 \\
\hline $407-47$ & 70 & 14 & 16 & 37 \\
\hline $407-49$ & 68 & 32 & 0 & 19 \\
\hline $407-54$ & 86 & 10 & 3 & 29 \\
\hline $407-56$ & 83 & 4 & 13 & 24 \\
\hline $407-59$ & 57 & 30 & 13 & 23 \\
\hline Tf8 & 61 & 39 & 0 & 41 \\
\hline Tf13 & 86 & 11 & 4 & 28 \\
\hline Tf14 & 44 & 54 & 3 & 39 \\
\hline Tf15 & 75 & 19 & 6 & 32 \\
\hline Tf16 & 75 & 25 & 0 & 16 \\
\hline $\mathrm{Ng} 72$ & 100 & 0 & 0 & 3 \\
\hline $\mathrm{Ng} 73$ & 80 & 20 & 0 & 5 \\
\hline $\mathrm{Ng} 74$ & 67 & 0 & 33 & 3 \\
\hline $\mathrm{Ng} 75$ & 33 & 67 & 0 & 3 \\
\hline Rua95 & 67 & 33 & 0 & 3 \\
\hline Rua96 & 100 & 0 & 0 & 3 \\
\hline Average/Total* & 64 & 31 & 6 & $504 *$ \\
\hline
\end{tabular}

According to previous studies (Kilgour et al. 2013; Lormand et al. 2020), TgVC magmas are water-poor magmas, which is confirmed by the prevalence of plagioclase-liquid pairs in equilibrium in the dry field

$\mathrm{Mg}$ and $\mathrm{Si}$ (see Supplementary Images_all). Fe and Mg are anti-correlated whereas $\mathrm{Mg}$ and $\mathrm{Al}$ are positively correlated. When Si oscillations are visible, they are positively correlated with $\mathrm{Fe}$. Commonly, the zonations in $\mathrm{Al}$ are fuzzier parallel to the b-axis or c-axis compared to the a-axis (see Supplementary Images_all). Similar to the plagioclases, pyroxene rim zones usually display oscillations that mantle a wide unzoned core, which may be resorbed (Fig. 9a). Using schematic mineral models, orthopyroxene crystals are usually observed as basal cuts, perpendicular to the c-axis (Krimer and Costa 2017). In some crystals, resorption, fracturing or truncating of crystal edges may also have occurred, which appear as discontinuous growth layers.

\section{Sector zoning}

Sector zoning appears in pyroxenes from Mangatawai and Ngauruhoe where there is intergrowth of Mg-rich (i.e. orthopyroxene) and Ca-rich (clinopyroxene) crystals
(Table 3 and Fig. 9b). The calcic sectors are not always homogeneous and are usually observed along the long axis (b-axis, c-axis or transversal, see Supplementary Images IIe), based on schematic mineral models. This texture affects crystals as small as $10 \mu \mathrm{m}$ and is cryptic in BSE images.

\section{Normal zoning}

The Mangatawai tephras contain normally zoned microcrysts where the core, which may have undergone resorption, is enriched in $\mathrm{Fe}$ and depleted in $\mathrm{Mg}$ and sometimes $\mathrm{Si}$ and $\mathrm{Cr}$ (see Supplementary Images_all), and where the outer layer is enriched in $\mathrm{Mg}(\mathrm{Si}$ and $\mathrm{Cr}$ ) and depleted in Fe. The compositional step between the two zones is generally sharp but also appears diffuse in some crystals (see Supplementary Images IIf).

\section{Reverse zoning}

In contrast to the plagioclase crystals, we find reversely zoned pyroxene microcrysts. They display a diffuse boundary between the Fe-rich and $\mathrm{Mg}$-poor highly resorbed core and the rim (Fig. 9d). A sharp boundary between the outer Mg-rich and Fe-poor layer and the thin $(\sim 2 \mu \mathrm{m}) \mathrm{Fe}$-enriched rim is also common. Reverse zoning is mostly observed in the 1972-1975 Ngauruhoe and Mangatawai tephras.

\section{Featureless microlites and nanolites}

Besides the textures described above, featureless crystals are also common. The microlites are euhedral to subhedral and do not show zonation or any internal structure, whereas the nanolites ( $\geq 30 \mathrm{~nm}$ but $<1 \mu \mathrm{m}$ in width) are generally acicular, related to high degrees of undercooling (Fig. 2; Mujin et al. 2017).

\section{Discussion}

The large variations in anorthite contents in plagioclases and $\mathrm{Mg} \#$ in pyroxenes (Fig. 3; Table 1) and the tangible disequilibrium inferred from crystal textures and mineral-liquid compositional pairs (Fig. 4 and Table 3) indicate that complex processes, some of which are similar to those affecting phenocryst populations, dominated the genesis of the $\mathrm{TgVC}$ microcryst populations. Besides, it is striking to see these textures at such small scales, especially for the pyroxene microcrysts where a single crystal may display several textures (e.g. see the Tufa Trig pyroxene in Table 3). Such a variety of compositions within the same eruptive deposit is 


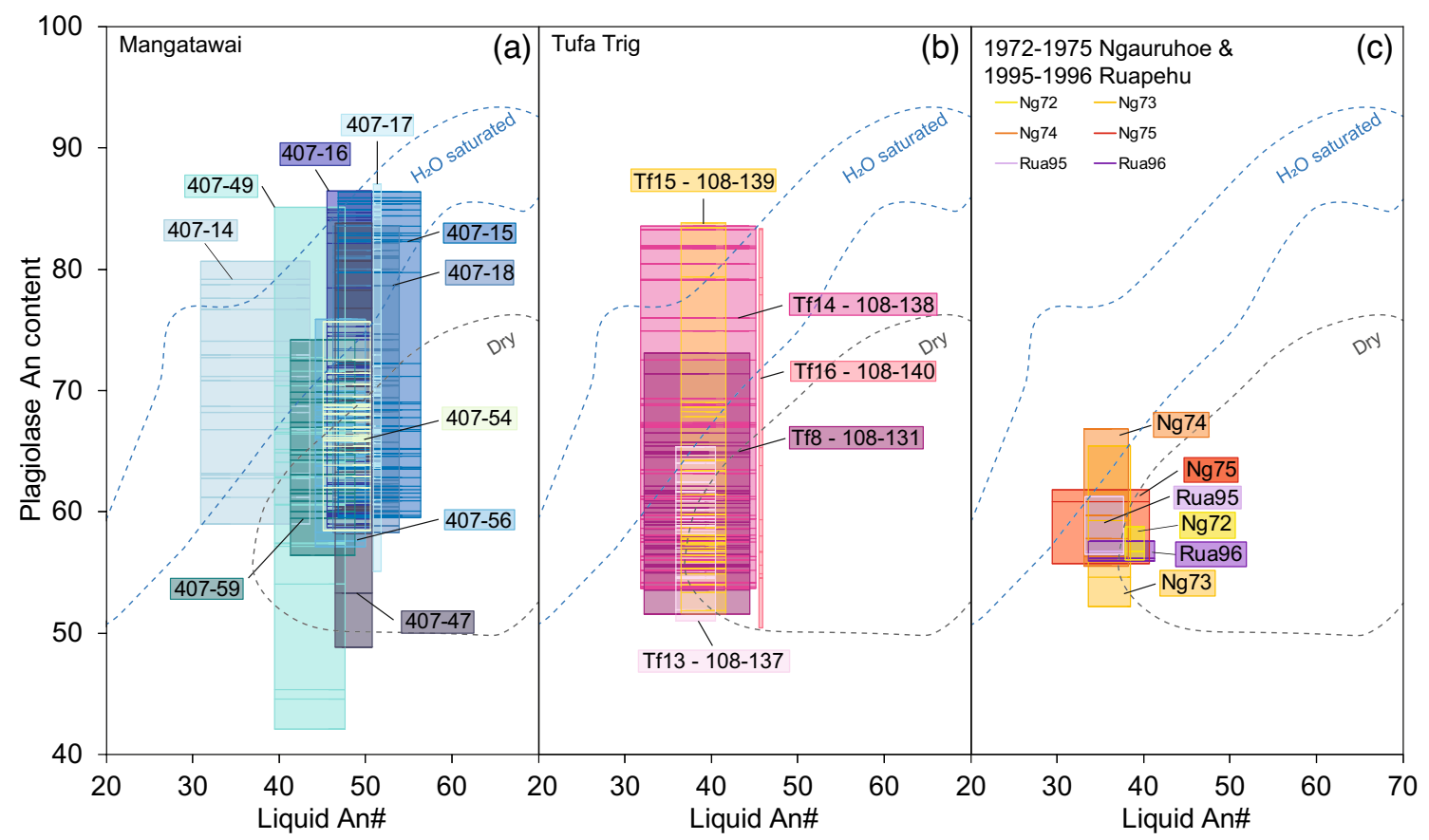

Fig. 5 Equilibrium assessment of the rims of plagioclase microlites and microcrysts from $\mathrm{TgVC}$ tephras. The $\mathrm{H}_{2} \mathrm{O}$-saturated and dry fields were determined experimentally for basaltic to rhyolitic composition by Waters and Lange (2015). Note that TgVC magmas have previously been determined to be unusually dry for arc magmas (Lormand et al. 2020) and thus, the plagioclase-liquid pairs falling above the lower limit of the $\mathrm{H}_{2} \mathrm{O}$-saturated field are considered out of equilibrium
Table 3 Summary table of number of images of plagioclase and pyroxene acquired using, respectively, (1) the Cameca IMS-1270 SIMS instrument equipped with a Stacked CMOS-type Active Pixel Sensor (SCAPS) and (2) the FE-SEM; JEOL JSM-7000F at IIL, Hokkaido University, Japan

\begin{tabular}{lllll}
\hline & Mangatawai & Tufa Trig & $\begin{array}{l}1972-1975 \\
\text { Ngauruhoe }\end{array}$ & Total \\
\hline $\begin{array}{l}\text { Plagioclase textures } \\
\text { (a) Resorption and overgrowth }\end{array}$ & $16(7)$ & $11(8)$ & $13(7)$ & $40(22)$ \\
$\begin{array}{l}\text { Plagioclase zonations } \\
\text { (b) Oscillatory zoning }\end{array}$ & 3 & 6 & 7 & 18 \\
(c) Normal (sharp) zoning & 8 & 5 & 4 & 12 \\
Pyroxenes textures & $37(9)$ & $4(1)$ & 2 & 10 \\
(a) Resorption and overgrowth & 7 & 1 & 4 & $57(15)$ \\
(b) Ca-rich bands & 7 & 1 & 3 & 12 \\
(c) Hollow textures & 5 & 1 & & 6 \\
Pyroxene zonations & & & 3 & 13 \\
(d) Oscillatory zoning & 9 & 1 & 3 & 6 \\
(e) Sector zoning & 3 & & 3 & 5 \\
(f) Normal zoning & 5 & & & 6 \\
(g) Reverse zoning & 1 & & & \\
\hline
\end{tabular}

Some images may appear in multiple categories. The actual numbers of images are provided in parentheses consistent with previous studies of phenocrysts from lavas of Ngauruhoe, Red Crater and Pukeonake (Coote and Shane 2016; Shane et al. 2019, 2017), but our dataset demonstrates that this is also seen in the microcrystic crystal cargo. Furthermore, $\sim 10-40 \%$ of the microlites are not in chemical equilibrium with their surrounding melts. There are caveats regarding the limited number of crystals investigated
(Table 3) which may prevent broader implications. However, most textures are found in each tephra formation and thus are commonplace and require interpretation. Besides, the occurrence of most microcryst textures across all volcanic vent systems is clear and indicates that similar magmatic processes must have affected the reservoir of these eruptions, as we discuss below. 


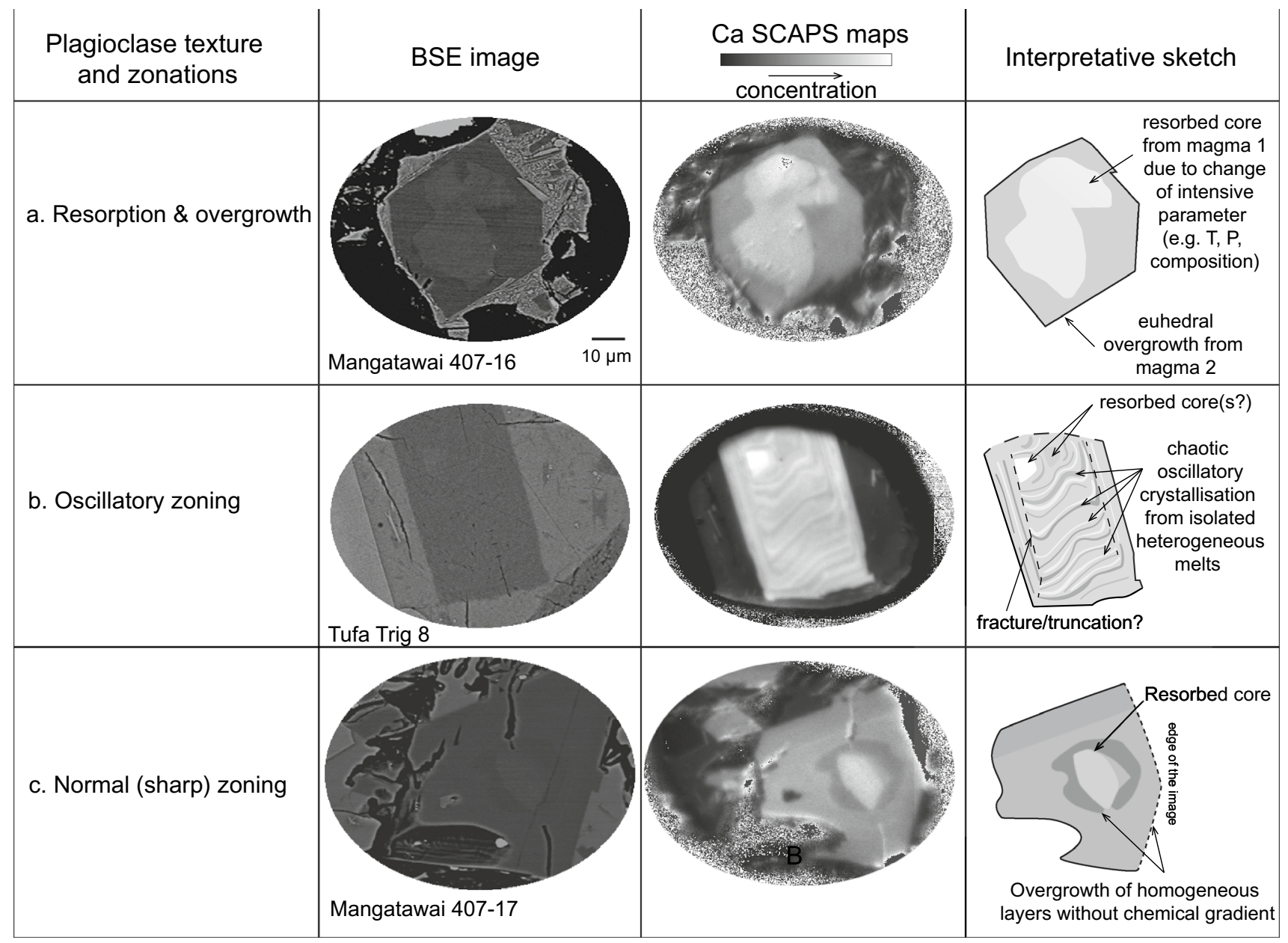

Fig. 6 Textures and zonations of microcrysts and microlites of plagioclase found in the TgVC tephras, including descriptions and interpretative sketches: a resorption and overgrowth characterised by a resorbed core and euhedral to subhedral overgrowthing rim; b oscillatory zoning where successive growth layers of differing compositions

\section{Magma mixing}

The broad range of glass and mineral compositions (Table 2) is a first piece of evidence for magma mixing. Although we acknowledge that crystallisation may generate local chemical variations in the melt, the predominance of disequilibrium between crystal rims and their surrounding glass compositions cannot be explained by local heterogeneities. Instead, such variabilities indicate that small heterogeneous and chemically distinct magma batches have intruded the system and crystallised.

In terms of textures, many plagioclase and pyroxene microcrysts show resorption followed by overgrowth, where a resorbed core is mantled by several concentric overgrowing layers (Fig. 6b, Fig. 9a and Supplementary Images Ia and IIb). This texture has been observed in the phenocrystic cargoes of some of the tephras (Mangatawai and Tufa form; and c normal (sharp) zoning, characterised by homogeneous zones, chemically distinct and separated by a distinct jump in composition. $\mathrm{Ca}, \mathrm{Si}$ and BSE respectively stand for calcium, silica and backscattered electron images. The $10 \mu \mathrm{m}$ scale is the same for all SCAPS images

Trig; Donoghue et al. 1997; Hobden et al. 2002; Zellmer et al. 2020) and indicates magma mixing or magma recharge (Agostini et al. 2013; Ubide et al. 2019a, b), which would lead to (over-)growth more magnesian pyroxene, as it was also interpreted from melt inclusion and crystal chemical data of the 1996 Ruapehu tephras (Kilgour et al. 2013, 2014). Magma mixing at TgVC is common and consistent with recent results on microlite size distributions of these formations (Lormand et al. 2020); indeed, kinking of CSD slopes is commonly linked to mixing of crystal populations (Higgins 2006; Jerram et al. 2003; Turner et al. 2003). In the case of $\mathrm{TgVC}$, featureless microlites as well as complexly zoned microlites and microcrysts coexist in the same melt, up to mid-crustal depths (Lormand et al. 2020). Furthermore, the large range and standard deviations of An contents and Mg\# (Fig. 3b and Table 1), and the $10-40 \%$ of mineral-liquid pairs in disequilibrium (Figs. 4 and 5) suggest 


\begin{tabular}{|c|c|c|c|}
\hline Pyroxene texture & BSE image & Chemical map & Interpretative sketch \\
\hline a. Resorption \& overgrowth & $407-14 \# 39$ & 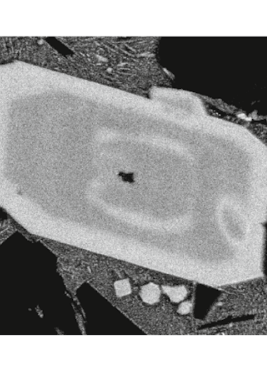 & $\begin{array}{c}\text { euhedral overgrowth } \\
\text { resorbed } \\
\text { layers }\end{array}$ \\
\hline b. Ca-rich bands & $\mathrm{Ng} 72 \# 26$ & & $\begin{array}{l}\mathrm{Ca}(-\mathrm{Cr}) \text { enrichment } \\
\text { near the rim along } \\
\text { the long axis }\end{array}$ \\
\hline c. Hollow texture & $407-15 \# 43$ & & $\begin{array}{l}\text { hopper core } \\
\text { overgrown } \\
\text { by a euhedral rim }\end{array}$ \\
\hline
\end{tabular}

Fig. 7 Textures of microcrysts and microlites of pyroxene found in the TgVC tephras, including descriptions and interpretative sketches: a resorption and overgrowth textures with a resorbed core and euhedral to subhedral overgrowth; b Ca-rich bands, occurring as $\mathrm{Ca}$ enrichment parallel to (100) plane; and $\mathbf{c}$ hollow texture highlight-

that the microcryst cargo originated from different magma batches. The feeding magmas may have been compositionally heterogeneous due to the mixing of several magma injections before eruption.

Plagioclase resorption can be triggered by volatile-undersaturated decompression events, which increase the water content of the magma and contract the plagioclase stability field (Bennett et al. 2019a, b; Nelson and Montana 1992). Resorbed crystals have previously been described as dominant features in plagioclase phenocrysts of lavas from Red Crater and Pukeonake (Shane et al. 2019), confirming that decompression events are common across the entire plumbing system.

Zoned pyroxenes (sharp normal and reverse) also suggest that magma mixing was a key process occurring at depth (Bennett et al. 2019a, b; Carrasco-Núñez et al. ing a remnant core of a hopper crystallisation. $\mathrm{Fe}, \mathrm{Ca}$ and BSE stand for iron, calcium and back-scattered electron images, respectively. The white scale bar at the bottom right corner of each BSE image is $10 \mu \mathrm{m}$

2012; Sakuyama 1984). In the case of normal zoning, the increase in Fe towards the rim may have resulted from a temperature decrease indicating mixing with more evolved magma. In contrast, reverse zoning may indicate mafic recharge (e.g. Bindeman 1993; Streck 2008). However, part of the reverse zoning observed in some pyroxenes and plagioclases may also result from decompression in a water-undersaturated melt. Indeed, phase-equilibrium experiments at constant temperature and water content (although for different compositions) suggest that decreasing total pressure in a water-undersaturated melt results in an increase of the $\mathrm{Mg}$ molar content of pyroxenes and of an increase of the Ca molar content of plagioclase crystals (e.g. Figure 6a of Andújar et al. 2016, or Fig. 8 of Solaro et al. 2019). 
Fig. 8 Different types of Ca-rich bands (purple arrow) observed in the pyroxene microlites and microcrysts, suggesting orthopyroxene (opx) and clinopyroxene (cpx) intergrowth with potential pigeonite exsolution (yellow arrows). A: thin Ca-rich bands along the (100) or (010) plane which appear discontinuous due to plagioclase ( $\mathrm{pl}$ ) crystallisation causing local partitioning effect. Note the discrete parallel lines (see white arrows) across the crystal and parallel to the hollow texture (h). B: thick Carich sectors in basal cuts. Note the discrete compositional lines parallel to the long axis within the pigeonite sectors of the lowermost crystal. C: chaotic $\mathrm{Ca}$ enrichment due to pigeonite exsolution. D: moderately thick Ca-enriched sector with a central compositional line, possibly pigeonitic in composition. $\mathbf{E}$ : clear intergrowth of an orthopyroxene core with clinopyroxene (100) sections in which "fractured bone"-like pigeonitic exsolution (yellow arrows) has started. The white scale bar at the bottom right corner of each BSE image is $10 \mu \mathrm{m}$
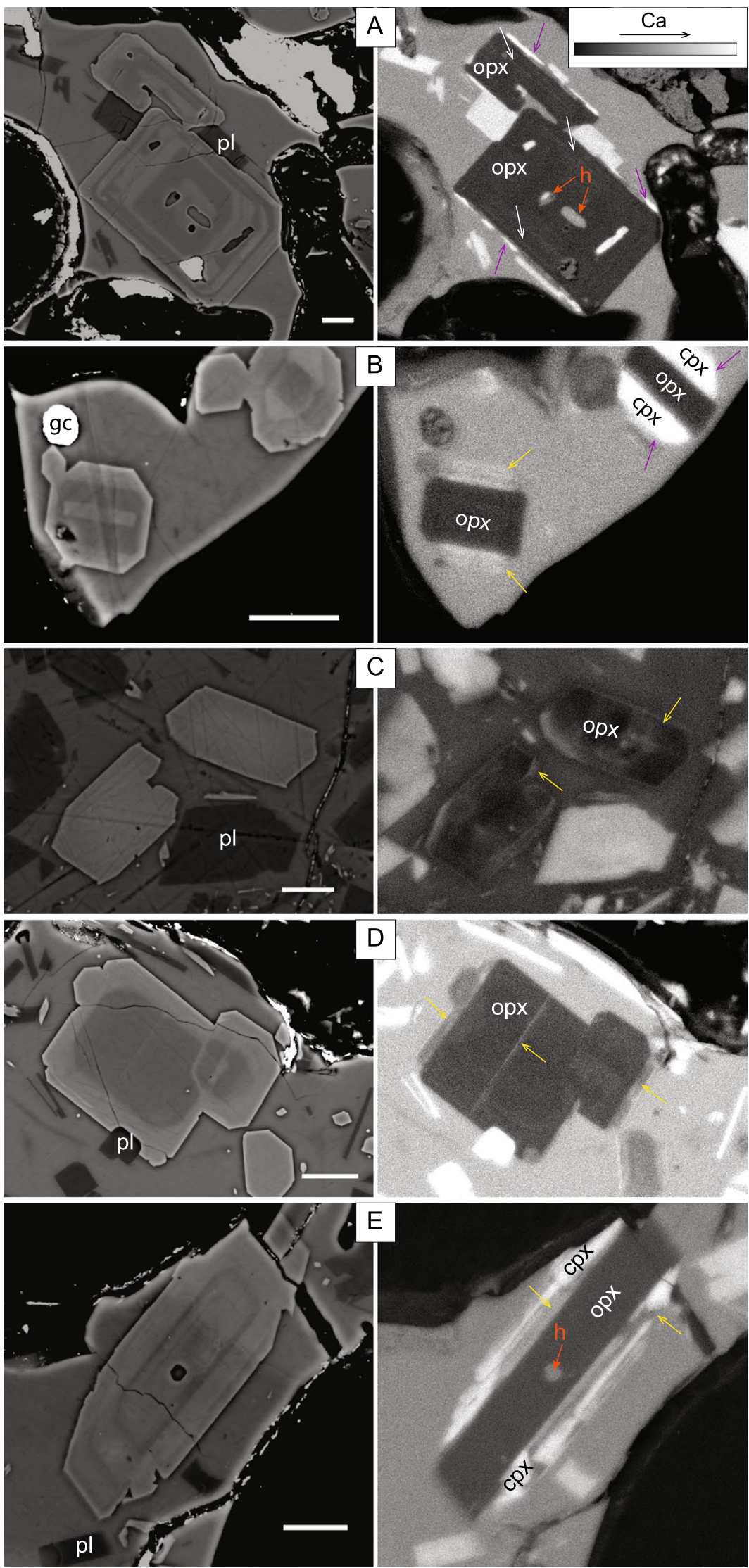


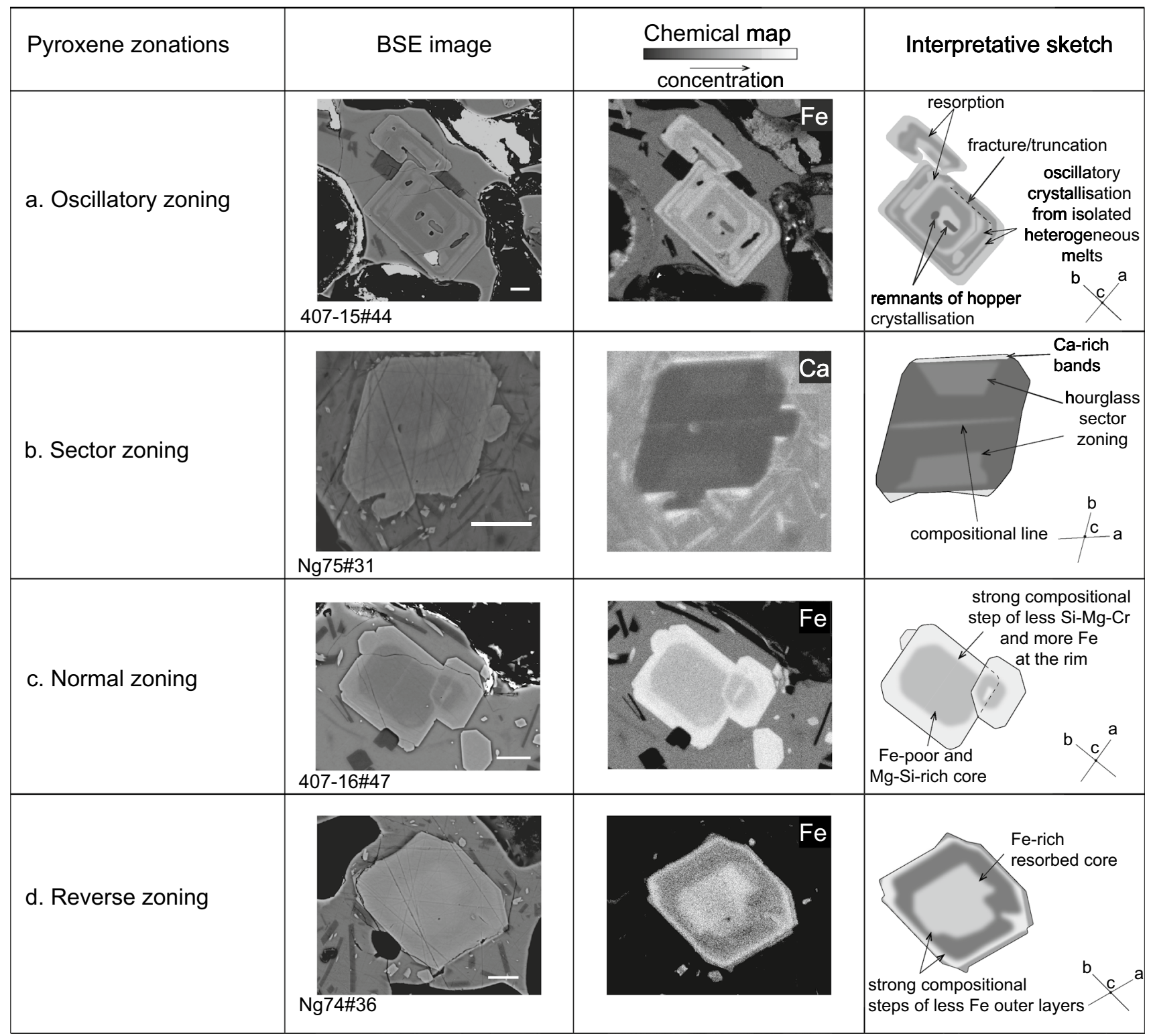

Fig. 9 Zonations of microlites and microcrysts of pyroxene found in TgVC tephras, including descriptions and interpretative sketches: a oscillatory zoning which generally mantled a resorbed cores and where fracture/truncation of growth layers is common; b sector zoning in basal cut as hourglass sector, often appearing as sector-zoned rims around an unzoned core; $\mathbf{c}$ normal zoning with a sharp boundary between the $\mathrm{Fe}$-poor core and the Fe-rich rim; and d reverse zoning between the Fe-rich resorbed core and the Fe-poor rim. The white scale bars at the bottom right corner of each BSE image is $10 \mu \mathrm{m}$

\section{Variable cooling rates throughout ascent}

Some textures provide evidence of variable cooling rates and may allow us to follow the chronology of events during ascent (Fig. 10). Indeed, a change of cooling rate may be inherent in magma ascent through dykes as initially they fracture through cold county rock, resulting in high heat loss through the dyke walls (Fig. 10a). The best texture reflecting this process is the remnant of hopper growth within the cores of pyroxenes (Fig. 7a, c, Fig. 8a, eand Fig. 9a, Supplementary Images IIc), which indicate that initial growth was associated with elevated cooling rates (e.g. Bennett et al. 2019a, b; Cashman 1988; Frey and Lange 2011). Besides, the substantial proportion of plagioclase-liquid pairs in the $\mathrm{H}_{2} \mathrm{O}$-saturated field and in disequilibrium (i.e. c. 30\%; Table 2) may suggest high cooling rates (Mollo et al. 2011a, b), which agree with crystallisation upon magma ascent.

Additional evidence for rapid crystal growth may be the abundance of $\mathrm{Al}$ oscillations in the orthopyroxenes 


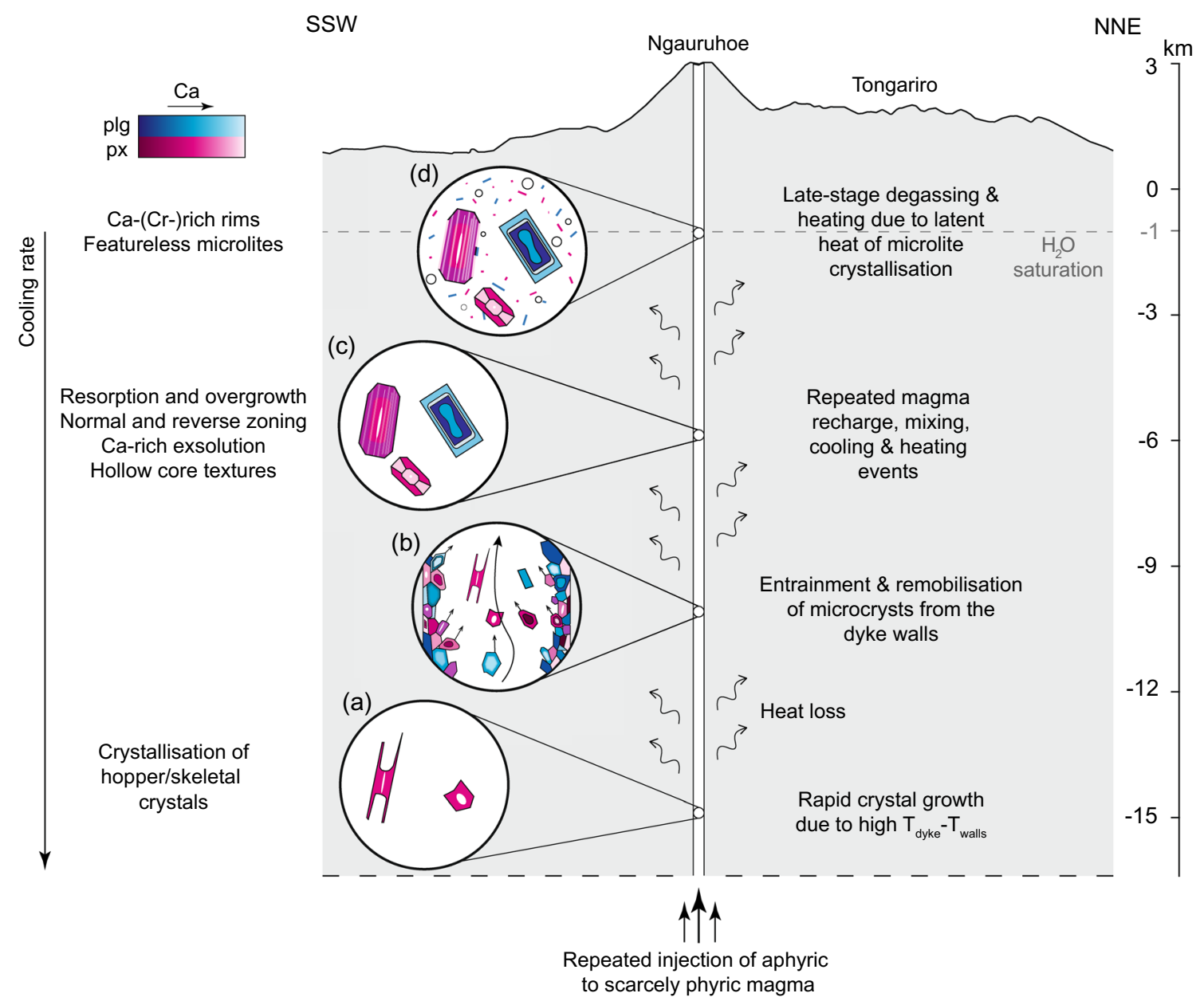

Fig. 10 Conceptual model of the magmatic processes and the resulting textures of the microantecrysts occurring throughout the conduit during ascent beneath the Tongariro Volcanic Centre. Aphyric melts ascend vertically, consistent with the regional tectonic setting where crustal extension is accommodated by dyking (Gómez-Vasconcelos et al. 2017), and a start crystallising hopper crystals at mid-crustal depths (Lormand et al. 2020) as a result of high undercooling due to the high temperature gradient between the melt and the dyke walls. b Repeated magma intrusions lead to entrainment and remobilisation of microcrysts of previous intrusions from the dyke walls, enabling

associated with diffuse boundaries parallel to b- and c-axes and sharp along the a-axis (Supplementary Images IId), particularly in the Mangatawai tephras. The fuzzy boundaries could result from anisotropic $\mathrm{Al}$ diffusion at magmatic temperature, consistent with the different types of boundaries (i.e. sharp versus fuzzy) observed within the crystals. However, as $\mathrm{Al}$ is an extremely slow diffusing element in orthopyroxene (Freer 1981; Freer et al. 1982; Witt-Eickschen and Seck 1991), such boundaries may in addition reflect rapid crystal growth (Allan et al. 2013), which leads to disequilibrium uptake of $\mathrm{Al}$, as observed experimentally in clinopyroxenes that experienced a fast cooling rate (Mollo et al. 2010). Although $\mathrm{Al}$ is incompatible in orthopyroxene crystal fracture and truncations. Magma ascent is accompanied by magma convection, and the temperature gradient between the dyke and the country rock decreases, and so does the cooling rate. c Crystals resorb due to crystal-magma mixing and crystal zonation forms through euhedral overgrowth. Moderate cooling rates induce Ca-rich exsolution of orthopyroxenes, and sector-zoned pyroxenes form. d Once the magma reaches water exsolution $(\sim 1 \mathrm{~km}$, Lormand et al. 2020 ), late-stage degassing occurs, triggering crystallisation of featureless microlites, which releases latent heat that in turn results in phase transformation, creating $\mathrm{Ca}-(\mathrm{Cr}-)$ rich rims in pyroxenes

(i.e. $\mathrm{Kd}_{\mathrm{Al}}{ }^{\text {opx-liq }}=0.43$; Adam and Green 2006), some orthopyroxenes may incorporate $\mathrm{Al}$ due to rapid growth and the formation of a melt boundary layer, which in turn yields local partitioning effects at the crystal-melt interface (Honour et al. 2019; Zellmer et al. 2016a, b). Both processes (e.g. rapid crystal growth and anisotropic diffusion) are not mutually exclusive and may have acted in tandem. Further, the incorporation of $\mathrm{Al}$ into clinopyroxene is strongly controlled by the degree of magma undercooling (Mollo et al. 2010; Ubide and Kamber 2018; Ubide et al. 2019a, b); indeed, Al incorporation into the tetrahedral site of clinopyroxene has been observed at the chilled margins of dykes due to higher cooling rates than the dyke interior (Coish and Taylor 1979; 
Mollo et al. 2011a, b). Ubide et al. (2019a, b) also associated sector-zoned clinopyroxene phenocrysts with kinetic effects at low degrees of undercooling, which can be linked to a range of processes taking place within a dyke: (i) slow magma ascent as expected in dykes where the rate of heat loss and the degree of friction with the dyke walls are high (e.g. Taisne and Jaupart 2011; Weinberg 1996); (ii) magma convection and mixing at the chilled margins of dyke (Di Stefano et al. 2020; Ubide et al. 2019a, b; Welsch et al. 2009); (iii) degassing, which increases the liquidus temperature of the magma and therefore the degree of undercooling (Klügel et al. 2020). Hence, $\mathrm{Al}$ oscillations and, more generally, oscillatory zoning found in our crystals may have occurred throughout the conduit as a result of fluctuations of crystallisation conditions (e.g. cooling rate).

Higher in the conduit, the temperature gradient between the inside of the dyke and the dyke walls eventually decreases due to heat loss from the dyke to the country rock, which in turn results in a decrease of the melt temperature via conduction (Pansino et al. 2019). Such temperature change results in a slower, moderate cooling rate, potentially creating favourable conditions for phase exsolution observed as Ca-rich lamellas in Ca-poor pyroxenes (Fig. 7c, Fig. 8a and Fig. 8d). Indeed, pigeonitic exsolution in orthopyroxenes has been described in microlites and nanolites from Ben Lomond obsidians from the Taupo Volcanic Zone (Sharp et al. 1996) where nanoscale pigeonite exsolution features were imaged parallel to the (100) and (001) planes using a TEM (Transmission Electron Miscroscopy). Such formation of pigeonite lamellae was attributed to pigeonite exsolution resulting from the incomplete spinodal decomposition caused by moderate cooling rates (Champness and Lorimer 1976). Spinodal decomposition occurs when there is a small change of concentration, such as what would be expected during magma recharge.

Finally, some pyroxenes show late-stage sector zoning, where Ca-rich rims overgrow unzoned cores (e.g. Figure $9 \mathrm{~b}$ and Supplementary Images IIe). Sector zoning in pyroxene microlites has before been observed (Humphreys et al. 2009; Zellmer et al. 2016a, b; Zellmer et al. 2018). In phenocrysts, sector zoning is often related to kinetic effects during crystal growth (e.g. Downes 1974; Ferguson 1973; Leung 1974; Nakamura 1973), and may take place at low degrees of undercooling (Masotta et al. 2020; Ubide et al. 2019a, b), suggesting cooling-induced crystallisation. Alternatively, undercooling conditions may be attained via degassing, which increases the liquidus temperature of the melt, as suggested to explain sector-zoned clinopyroxene rims in the 2014-2015 eruption of Fogo, Cape Verde Islands (Klügel et al. 2020). In our study, we suggest that cores may have crystallised in response to high undercooling, whereas rims may have crystallised at shallower depth upon volatile exsolution (Lormand et al. 2020). It may be possible that such late-stage degassing could also explain the change of liquidus temperature and thus the change of composition necessary to trigger phase transformation expressed by the orthopyroxene-clinopyroxene intergrowth and the $\mathrm{Ca}-(\mathrm{Cr}-)$ rich rims described in this study (Fig. 7b and Fig. 8b, e). These processes may be occurring in the shallowest part of the conduit, potentially by heating-induced due to latent heat of crystallisation of the $\mathrm{H}_{2} \mathrm{O}$-saturated melt (Glazner 2019).

\section{(Over)growth in aphyric magmas}

Plagioclase microcrysts from all tephras, but especially from the Mangatawai and Ngauruhoe Formations, are characterised by sharp zoning between calcic cores and sodic rims, except for crystals from the Mangamate Formation, which show the opposite pattern. Sharp zoning between cores and rims provides further evidence of crystal entrainment in a foreign melt. Apparently, the magmas did not significantly change composition during crystallisation, which is reflected by the absence of chemical gradient within the core of plagioclase crystals. In this case, the volume of the melt in which the crystal rim grew must have been large relative to the volume of the crystal cargo, because the overgrowth of the few existing crystals would not have significantly affected the composition of their carrier melt. This suggests that the melts in which the crystal rims grew were aphyric or very sparsely phyric. Sharp jumps between the calcic core and a more sodic rim were also observed in plagioclase phenocrysts from Stromboli in Italy (Armienti et al. 2007), from Gakkel Ridge MORBs (Bennett et al. 2019a, b), and also from monogenetic volcanoes of the Kaikohe-Bay of Islands field in New Zealand (Coote et al. 2018). These observations may indicate that in these settings, the propagation of aphyric or sparsely phyric melt bodies are a key aspect of crustal magma ascent processes. By extension, the ascent of largely aphyric melts into dykes transporting foreign crystals may occur more readily than generally acknowledged.

\section{An antecrystic origin of a substancial proportion of TgVC microcrysts}

Chemical and textural features point towards an antecrystic origin for many microlites and microcrysts erupted during the explosive eruptions of $\mathrm{TgVC}$. Indeed, the variety of textures described in the majority of the micrometre-sized crystal cargo, and the broad range of both glass and mineral compositions, indicate that much of the microcrystic cargo crystallised mostly due to cooling during ascent rather than due to degassing within the conduit, as often inferred for microlite crystallisation (e.g. Hammer et al. 1999; Noguchi et al. 2006; Renjith 2014; Szramek et al. 2006). Instead, 
microlites exhibit similar textures to those described in antecrystic phenocrysts in previous studies of the TgVC (Arpa et al. 2017; Auer et al. 2015; Shane et al. 2019, 2007, 2017; Zellmer et al. 2020). Furthermore, different tephras from different sources all display similar textures and, thus, must have been affected by similar magmatic processes, which indicates a commonality in time and space for the shallow magma plumbing systems beneath the TgVC (Fig. 10). While previous studies described an interaction of ascending melts with crystal mush zones as a possible scenario beneath TgVC (Beier et al. 2017; Kilgour et al. 2013, 2014; Nakagawa et al. 1999; Shane et al. 2007, 2017), the present study provides textural and compositional evidence of the processes occurring in the upper conduit prior to eruption. Here, the microcrystic crystal cargo originated from rapidly cooled and thus fine-grained intrusions before being remobilised and transported by new and unusually hot magmas (Lormand et al. 2020). Remobilisation of small crystals from solidified dykes may be the reason for overgrown fractures seen in some microcrysts (Fig. 6b and Fig. 9a). Repeated remobilisation and intrusions prior to ultimate uptake into the erupting magma batch may lead to the complexity of textures observed for some crystals. A vertical magmatic plumbing system consisting of dykes is also consistent with the tectonic regime of the area; indeed, a study of the Tongariro graben (Gómez-Vasconcelos et al. 2017) defined an extension rate of $c .7 \mathrm{~mm} / \mathrm{yr}$ since $20 \mathrm{ka}$, which is partly accommodated by dyke intrusions. Most of the intruded dykes would not reach the surface and thus solidify in the upper crust. In this case, we infer that such intrusions may have been responsible for triggering the Upper Te Maari phreatic eruption in 2012 (e.g. Breard et al. 2014). Eventually, a larger crystal-poor magma injection would have fractured upwards through this environment, recycling crystals with a wide spectrum of textures. Shallow ascent of $\mathrm{H}_{2} \mathrm{O}$-saturated melts results in heating through latent heat release of microlite crystallisation (Blundy et al. 2006; Glazner 2019), forming some more featureless microlites and the $\mathrm{Ca}-(\mathrm{Cr}-)$ rich rims observed in some pyroxene microantecrysts.

\section{Conclusions}

The Tongariro Volcanic Centre tephras have crystal cargoes with various and complex textures, recording a wide range of magmatic processes.

1. A significant proportion (c. 10-40\%) of microlites $(<30 \mu \mathrm{m}$ in width) and microcrysts $(>30$ in width but $<100 \mu \mathrm{m}$ in length) from tephras of the $\mathrm{TgVC}$ are not in chemical equilibrium with their surrounding glass. This is consistent with the ubiquitous resorption and overgrowth textures observed in plagioclases and pyroxenes.

2. Microcrysts, as well as some microlites, display textural complexities, some of which are similar to those commonly recorded by larger crystals $(>100 \mu \mathrm{m}$ in length) seen in previous studies. These complexities indicate that the small crystals (i.e. microcrysts) have growth histories that include similar processes to those involved during the growth of the larger crystals (i.e. phenocrysts). Magma mixing, for instance, is highlighted by resorption and overgrowth, sharp normal zoning, and reverse zoning. Oscillatory zoning is interpreted to reflect fluctuations in the degree of undercooling. None of these textures have previously been described in microlites and microcrysts from $\mathrm{TgVC}$ andesites.

3. Remobilisation of the micrometre-sized crystal cargo implies uptake of crystals from fine-grained intrusives, likely dykes that were previously injected into the subvolcanic system and solidified rapidly. Entrainment and remobilisation of microlites and microcrysts may involve crystal fracturing.

4. Cooling rate fluctuates during the ascent and is recorded by some of the pyroxene textures. Initially and at the deepest level (mid-crustal depths, Lormand et al. 2020), rapid cooling due to a high temperature gradient between the intruding melt and the dyke walls results in hollow textures observed in the cores of some pyroxene microcrysts and interpreted as remnants of early hopper growth. Shallower, where heat loss from the dyke to the country rock has occurred, a more moderate cooling rate is reflected by Ca-rich exsolution and sector zoning in pyroxenes. In the last few hundred metres $(<1 \mathrm{~km}$ depth), the $\mathrm{H}_{2} \mathrm{O}$-saturated melts begin to degas, inducing crystallisation of featureless microlites, which in turn releases latent heat, responsible for the narrow calcic rim formation on pyroxenes.

5. Our data imply a complex subvolcanic system dominated by dyking events of small, sparsely phyric magma batches that solidify rapidly, and eruption of a largely microantecrystic crystal cargo. In the extensional setting of the $\mathrm{TgVC}$, deeper magma reservoirs may contribute larger mesoantecrysts to volcanic eruptives.

This study provides new insights into magmatic processes through micrometre-scale textures of the crystal cargo. The use of high-resolution imaging, such as elemental maps and SCAPS detectors in SIMS on microlites and microcrysts, reveals complexities in these smallest crystals that appear featureless in conventional BSE images, making it possible to link cryptic internal crystal structures and textures to crystal growth dynamics immediately before eruption. 
Supplementary Information The online version contains supplementary material available at https://doi.org/10.1007/s00410-021-01857-7.

Acknowledgements We thank Silvio Mollo and an anonymous reviewer for their constructive comments, which greatly improved this script, and Othmar Müntener for editorial handling. CL is grateful to GNS Science Wairakei for giving permission to use its samples. We would like to thank Minami Kuroda and Ryosuke Fujita for help with the SCAPS imaging. This work was supported by a Ministry of Business, Innovation and Employment grant (MAUX1507) to GFZ. GK is supported by the Hazards and Risk Management Programme which is supported by New Zealand Strategic Science Investment Funding (SSIF) from the New Zealand Ministry of Business, Innovation \& Employment (MBIE). TU is supported by a Foundation Research Excellence Award from The University of Queensland (UQ-FREA RM2019001828).

Open Access This article is licensed under a Creative Commons Attribution 4.0 International License, which permits use, sharing, adaptation, distribution and reproduction in any medium or format, as long as you give appropriate credit to the original author(s) and the source, provide a link to the Creative Commons licence, and indicate if changes were made. The images or other third party material in this article are included in the article's Creative Commons licence, unless indicated otherwise in a credit line to the material. If material is not included in the article's Creative Commons licence and your intended use is not permitted by statutory regulation or exceeds the permitted use, you will need to obtain permission directly from the copyright holder. To view a copy of this licence, visit http://creativecommons.org/licenses/by/4.0/.

\section{References}

Adam J, Green T (2006) Trace element partitioning between micaand amphibole-bearing garnet lherzolite and hydrous basanitic melt: 1. Experimental results and the investigation of controls on partitioning behaviour. Contrib Mineral Petrol 152(1):1-17. https://doi.org/10.1007/s00410-006-0085-4

Agostini C, Fortunati A, Arzilli F, Landi P, Carroll MR (2013) Kinetics of crystal evolution as a probe to magmatism at Stromboli (Aeolian Archipelago, Italy). Geochim Cosmochim Acta 110:135-151. https://doi.org/10.1016/j.gca.2013.02.027

Allan ASR, Morgan DJ, Wilson CJN, Millet M-A (2013) From mush to eruption in centuries: assembly of the super-sized Oruanui magma body. Contrib Mineral Petrol 166:143-164. https://doi. org/10.1007/s00410-013-0869-2

Andújar K, Scaillet B, Pichavant M, Druitt TH (2016) Generation conditions of dacite and rhyodacite via the crystallization of an andesitic magma. Implications for the plumbing system at Santorini (Greece) and the origin of Tholeiitic or Calc-alkaline differentiation trends in arc magmas. J Petrol 57(10):1887-1920. https://doi.org/10.1093/petrology/egw061

Armienti P, Francalanci L, Landi P (2007) Textural effects of steady state behaviour of the Stromboli feeding system. J Volcanol Geoth Res 160(1-2):86-98. https://doi.org/10.1016/j.jvolg eores.2006.05.004

Arpa MC, Zellmer GF, Christenson BW, Lube G, Shellnutt JG (2017) Variable magma reservoir depths for Tongariro volcanic complex eruptive deposits from 10,000 years to present in preparation. Bull Volcanol 79:56. https://doi.org/10.1007/ s00445-017-1137-5

Arzilli F, La Spina G, Burton MR, Polacci M, Le Gall N, Hartley ME, Di Genova D, Cai B, Vo NT, Bamber EC, Nonni S, Atwood R,
Llewellin EW, Brooker RA, Mader HM, Lee PD (2019) Magma fragmentation in highly explosive basaltic eruptions induced by rapid crystallization. Nat Geosci 12:1023-1028. https://doi.org/ 10.1038/s41561-019-0468-6

Auer A, Martin CE, Palin JM, White JDL, Nakagawa M, Stirling $C$ (2015) The evolution of hydrous magmas in the Tongariro volcanic centre: the 10 ka Pahoka-Mangamate eruptions. NZ J Geol Geophys 58(4):364-384. https://doi.org/10.1080/00288306. 2015.1089913

Bachmann O, Bergantz GW (2004) On the origin of crystal-poor rhyolites: extracted from batholithic crystal mushes. J Petrol 45(8):1565-1582. https://doi.org/10.1093/petrology/egh019

Bachmann O, Bergantz GW (2006) Gas percolation in upper-crustal silicic crystal mushes as a mechanism for upward heat advection and rejuvenation of near-solidus magma bodies. J Volcanol Geoth Res 149(1-2):85-102. https://doi.org/10.1016/j.jvolg eores.2005.06.002

Beier C, Haase KM, Brandl PA, Krumm SH (2017) Primitive andesites from the Taupo volcanic zone formed by magma mixing. Contrib Mineral Petrol. https://doi.org/10.1007/s00410-017-1354-0

Bennett EN, Lissenberg CJ, Cashman KV (2019) The signifcance of plagioclase textures in mid-ocean ridge basalt (Gakkel Ridge, Arctic Ocean). Contrib Mineral Petrol. https://doi.org/10.1007/ s00410-019-1587-1

Bennett EN, Lissenberg CJ, Cashman KV (2019b) The significance of plagioclase textures in mid-ocean ridge basalt (Gakkel Ridge, Arctic Ocean). Contrib Mineral Petrol 174(6):49. https://doi.org/ 10.1007/s00410-019-1587-1

Berlo K, Blundy J, Turner S, Hawkesworth C (2007) Textural and chemical variation in plagioclase phenocrysts from the 1980 eruptions of Mount St. Helens, USA. Contrib Mineral Petrol 154:291-308. https://doi.org/10.1007/s00410-007-0194-8

Bindeman IN (1993) A practical petrological method for the determination of volume proportions of magma chamber refilling. J Volcanol Geoth Res 56(1):133-144. https://doi.org/10.1016/ 0377-0273(93)90055-V

Blundy J, Cashman KV, Humphreys M (2006) Magma heating by decompression-driven crystallization beneath andesite volcanoes. Nature 443:76-80. https://doi.org/10.1038/nature05100

Bragagni A, Avanzinelli R, Freymuth H, Francalanci L (2014) Recycling of crystal mush-derived melts and short magma residence times revealed by U-series disequilibria at Stromboli volcano. Earth Planet Sci Lett 404:206-219. https://doi.org/10.1016/j. eps1.2014.07.028

Breard ECP, Lube G, Cronin SJ, Fitzgerald R, Kennedy B, Scheu B, Montanaro C, White JDL, Tost M, Procter JN, Moebis A (2014) Using the spatial distribution and lithology of ballistic blocks to interpret eruption sequence and dynamics: August 62012 Upper Te Maari eruption, New Zealand. J Volcanol Geoth Res 286:373-386. https://doi.org/10.1016/j.jvolgeores.2014.03.006

Carrasco-Núñez G, McCurry M, Branney MJ, Norry M, Willcox C (2012) Complex magma mixing, mingling, and withdrawal associated with an intra-Plinian ignimbrite eruption at a large silicic caldera volcano: Los Humeros of central Mexico. GSA Bull 124(11-12):1793-1809. https://doi.org/10.1130/b30501.1

Cashman KV (1988) Crystallization of Mount St. Helens 1980-1986 dacite: a quantitative textural approach. Bull Volcanol 50(3):194209. https://doi.org/10.1007/BF01079682

Cashman KV, Blundy J (2000) Degassing and crystallization of ascending andesite and dacite. Philos Trans R Soc Lond A 358:14431464. https://doi.org/10.1098/rsta.2000.0600

Cashman KV, Blundy J (2013) Petrological cannibalism: the chemical and textural consequences of incremental magma body growth. Contrib Mineral Petrol 166:703-729. https://doi.org/10.1007/ s00410-013-0895-0 
Cashman KV, Sparks RSJ, Blundy J (2017) Vertically extensive and unstable magmatic systems: a unified view of igneous processes. Science. https://doi.org/10.1126/science.aag3055

Castro JM, Mercer C (2004) Microlite textures and volatile contents of obsidian from the Inyo volcanic chain, California. Geophys Res Lett. https://doi.org/10.1029/2004g1020489

Champness P, Lorimer GW (1976) Exsolution in silicates. In: Wenk HR (ed) Electron microscopy in mineralogy. Springer, Berlin, Heidelberg

Civetta L, Galati R, Santacroce R (1991) Magma mixing and convective compositional layering within the Vesuvius magma chamber. Bull Volcanol 53(4):287-300. https://doi.org/10.1007/BF004 14525

Coish RA, Taylor LA (1979) The effects of cooling rate on texture and pyroxene chemistry in DSDP Leg 34 basalt: a microprobe study. Earth Planet Sci Lett 42(3):389-398. https://doi.org/10. 1016/0012-821X(79)90048-7

Cole JW (1978) Andesites of the Tongariro volcanic centre, North Island, New Zealand. J Volcanol Geoth Res 3:121-153. https:// doi.org/10.1016/0377-0273(78)90007-0

Coote AC, Shane P (2016) Crystal origins and magmatic system beneath Ngauruhoe volcano (New Zealand) revealed by plagioclase textures and compositions. Lithos 260:107-119. https://doi. org/10.1016/j.lithos.2016.05.017

Coote A, Shane P, Stirling C, Reid M (2018) The origin of plagioclase phenocrysts in basalts from continental monogenetic volcanoes of the Kaikohe-Bay of Islands field, New Zealand: implications for magmatic assembly and ascent. Contrib Mineral Petrol. https://doi.org/10.1007/s00410-018-1440-y

Costa A, Caricchi L, Bagdassarov N (2009) A model for the rheology of particle-bearing suspensions and partially molten rocks. Geochem Geophys Geosyst 10:1-13. https://doi.org/10.1029/ 2008GC002138

Costa F, Coogan LA, Chakraborty S (2010) The time scales of mixing and mingling involving primitive melts and melt-mush interaction at Mid-ocean ridges. Contrib Mineral Petrol 159:371-387. https://doi.org/10.1007/s00410-009-0432-3

Di Stefano F, Mollo S, Ubide T, Petrone CM, Caulfield J, Scarlato P, Nazzari M, Andronico D, Del Bello E (2020) Mush cannibalism and disruption recorded by clinopyroxene phenocrysts at Stromboli volcano: new insights from recent 2003-2017 activity. Lithos 360-361:105440. https://doi.org/10.1016/j.lithos. 2020.105440

Donoghue SL, Neall VE, Palmer AS (1995) Stratigraphy and chronology of late quaternary andesitic tephra deposits, Tongariro volcanic centre, New Zealand. J R Soc N Z 25:115-206. https:// doi.org/10.1080/03014223.1995.9517487

Donoghue SL, Neall VE, Palmer AS, Stewart RB (1997) The volcanic history of Ruapehu during the past 2 millennia based on the record of Tufa Trig tephras. Bull Volcanol 59:136-146. https:// doi.org/10.1007/s004450050181

Downes MJ (1974) Sector and oscillatory zoning in calcic augites from M. Etna, Sicily. Contrib Mineral Petrol 47(3):187-196. https:// doi.org/10.1007/BF00371538

Ferguson AK (1973) On hour-glass sector zoning in clinopyroxene. Mineral Mag 39(303):321-325. https://doi.org/10.1180/minmag. 1973.039.303.08

Freer R (1981) Diffusion in silicate minerals and glasses: a data digest and guide to the literature. J Petrol 76:440-454. https://doi.org/ 10.1007/BF00371486

Freer R, Carpenter MA, Long JVP, Reed SJB (1982) "Null result" diffusion experiments with diopside: implications for pyroxene equilibria. Earth Planet Sci Lett 58:285-292. https://doi.org/10. 1016/0012-821X(82)90201-1

Frey HM, Lange RA (2011) Phenocryst complexity in andesites and dacites from the tequila volcanic field, Mexico: resolving the effects of degassing vs. magma mixing. Contrib Mineral Petrol 162(2):415-445. https://doi.org/10.1007/s00410-010-0604-1

Giacomoni PP, Ferlito C, Coltorti M, Bonadiman C, Lanzafame G (2014) Plagioclase as archive of magma ascent dynamics on "open conduit" volcanoes: the 2001-2006 eruptive period at Mt.Etna. Earth-Sci Rev 138:371-393. https://doi.org/10.1016/j. earscirev.2014.06.009

Glazner AF (2019) The ascent of water-rich magma and decompression heating: a thermodynamic analysis. Am Mineral 104(6):890896. https://doi.org/10.2138/am-2019-6925

Gómez-Vasconcelos MG, Villamor P, Cronin SJ, Procter JN, Palmer AS, Townsend DB, Leonard G (2017) Crustal extension in the Tongariro graben, New Zealand: insights into volcano-tectonic interactions and active deformation in a young continental rift. Geol Soc Am 129(9/10):1085-1099. https://doi.org/10.1130/ B31657.1

Grove TL, Baker MB, Kinzler RJ (1984) Coupled CaAl-NaSi diffusion in plagioclase feldspar: experiments and applications to cooling rate speedometry. Geochim Cosmochim Acta 48:2113-2121. https://doi.org/10.1016/0016-7037(84)90391-0

Halden NM, Hawthorne FC (1993) The fractal geometry of oscillatory zoning in crystals: application to zircon. Am Mineral 78(9-10):1113-1116

Hammer JE, Rutherford MJ (2002) An experimental study of the kinetics of decompression-induced crystallization in silicic melt. J Geophys Res. https://doi.org/10.1029/2001JB000281

Hammer J, Cashman KV, Hoblitt R, P., Newman S, (1999) Degassing and microlite crystallization during pre-climatic events of the 1991 eruption of Mt. Pinatubo, Philippines. Bull Volcanol 60:355-380. https://doi.org/10.1007/s004450050238

Hammer JE, Cashman KV, Voight B (2000) Magmatic processes revealed by textural and compositional trends in Merapi dome lavas. J Volcanol Geoth Res 100(1-4):165-192. https://doi.org/ $10.1016 / \mathrm{S} 0377-0273(00) 00136-0$

Higgins MD (2006) Verification of ideal semi-logarithmic, lognormal or fractal crystal size distributions from 2D datasets. J Volcanol Geoth Res 154(1-2):8-16. https://doi.org/10.1016/j.jvolgeores. 2005.09.015

Hobden BJ, Houghton BF, Davidson JP, Weaver SD (1999) Small and short-lived magma batches at composite volcanoes: time windows at Tongariro volcano, New Zealand. J Geol Soc Lond 156:865-868. https://doi.org/10.1144/gsjgs.156.5.0865

Hobden BJ, Houghton BF, Nairn IA (2002) Growth of a young, frequently active composite cone: Ngauruhoe volcano, New Zealand. Bull Volcanol 64(6):392-409. https://doi.org/10.1007/ s00445-002-0216-3

Honour VC, Holness MB, Charlier B, Piazolo SC, Namur O, Prosa TJ, Martin I, Helz RT, Maclennan J, Jean MM (2019) Compositional boundary layers trigger liquid unmixing in a basaltic crystal mush. Nat Commun 10(1):4821. https://doi.org/10.1038/ s41467-019-12694-5

Humler E, Whitechurch H (1988) Petrology of basalts from the Central Indian Ridge (lat. $25^{\circ} 23^{\prime} \mathrm{S}$, long. $70^{\circ} 04^{\prime} \mathrm{E}$ ): estimates of frequencies and fractional volumes of magma injections in a two-layered reservoir. Earth Planet Sci Lett 88:169-181. https://doi.org/10. 1016/0012-821X(88)90055-6

Humphreys MCS, Christopher T, Hards V (2009) Microlite transfer by disaggregation of mafic inclusions following magma mixing at Soufrière Hills volcano, Montserrat. Contrib Mineral Petrol 157:609-624. https://doi.org/10.1007/s00410-008-0356-3

Jerram DA, Martin VM (2008) Understanding crystal populations and their significance through the magma plumbing system. Geol Soc Lond Spec Publ 304(1):133. https://doi.org/10.1144/SP304.7

Jerram DA, Cheadle MJ, Philpotts AR (2003) Quantifying the building blocks of igneous rocks: are clustered crystal frame- works 
the foundation? J Petrol 44:2033-2051. https://doi.org/10.1093/ petrology/egg069

Jerram D, Dobson KJ, Morgan D, Pankhurst MJ (2018) Chapter 8. The petrogenesis of magmatic systems: using igneous textures to understand magmatic processes. In: Burchardt S (ed) Volcanic and igneous plumbing systems. Elsevier, pp 191-229

Kilgour GN, Blundy J, Cashman KV, Mader HM (2013) Small volume andesite magmas and melt-mush interactions at Ruapehu, New Zealand: evidence from melt inclusions. Contrib Mineral Petrol 166:371-392. https://doi.org/10.1007/s00410-013-0880-7

Kilgour GN, Saunders KE, Blundy JD, Cashman KV, Scott BJ, Miller CA (2014) Timescales of magmatic processes at Ruapehu volcano from diffusion chronometry and their comparison to monitoring data. J Volcanol Geoth Res 288:62-75. https://doi.org/10. 1016/j.jvolgeores.2014.09.010

Kim D, Brown LD, Árnason K, Gudmundsson O, Ágústsson K, Flóvenz OG (2018) Magma "bright spots" mapped beneath Krafla, Iceland, using RVSP imaging of reflected waves from microearthquakes. J Volcanol Geoth Res. https://doi.org/10. 1016/j.jvolgeores.2018.04.022

Klügel A, Day S, Schmid M, Faria B (2020) Magma plumbing during the 201T 2015 eruption of Fogo (Cape Verde Islands). Front Earth Sci 8:157. https://doi.org/10.3389/feart.2020.00157

Krimer D, Costa F (2017) Evaluation of the effects of 3D diffusion, crystal geometry, and initial conditions on retrieved time-scales from $\mathrm{Fe}-\mathrm{Mg}$ zoning in natural oriented orthopyroxene crystals. Geochim Cosmochim Acta 196:271-288. https://doi.org/10. 1016/j.gca.2016.09.037

Lasaga AC (1982) Toward a master equation in crystal growth. Am J Sci 282:1264-1288. https://doi.org/10.2475/ajs.282.8.1264

Le Bas MJ, Le Maitre RW, Streckeisen A, Zanettin P (1986) A chemical classification of volcanic rocks based on the total alkali-silica diagram. J Petrol 27:745-750. https://doi.org/10.1093/petrology/ 27.3.745

Leung IS (1974) Sector-zoned titanaugites: morphology, crystal chemistry, and growth. Am Mineral 59(1-2):127-138

Longpré M-A, Troll VR, Walter TR, Hansteen TH (2009) Volcanic and geochemical evolution of the Teno massif, Tenerife, Canary Islands: some repercussions of giant landslides on ocean island magmatism. Geochem Geophys Geosyst. https://doi.org/10.1029/ 2009GC002892

Lormand C, Zellmer GF, Németh K, Kilgour GN, Mead S, Palmer AS, Sakamoto N, Yurimoto H, Moebis A (2018) Weka trainable segmentation plugin in ImageJ: a semi-automatic tool applied to crystal size distributions of microlites in volcanic rocks. Microsc Microanal 24(6):667-675. https://doi.org/10.1017/s143192761 8015428

Lormand C, Zellmer GF, Kilgour G, Nemeth K, Palmer AS, Sakamoto N, Yurimoto H, Kuritani T, Moebis A (2020) Slow ascent of unusually hot intermediate magmas triggering Strombolian to Plinian eruptions. J Petrol. https://doi.org/10.1093/petrology/egaa077

MacKenzie WS, Donaldson CH, Guilford C (1982) Atlas of igneous rocks and their textures. Wiley, p 148

Marsh BD (1981) On the crystallinity, probability of occurrence, and rheology of lava and magma. Contrib Mineral Petrol 78(1):8598. https://doi.org/10.1007/BF00371146

Martel C (2012) Eruption dynamics inferred from microlite crystallization experiments: application to Plinian and dome-forming eruptions of Mt. Pelée (Martinique, Lesser Antilles). J Petrol 53(4):699-725. https://doi.org/10.1093/petrology/egr076

Martin VM, Holness MB, Pyle DM (2006) Textural analysis of magmatic enclaves from the Kameni Islands, Santorini, Greece. J Volcanol Geoth Res 154(1):89-102. https://doi.org/10.1016/j. jvolgeores.2005.09.021

Masotta M, Pontesilli A, Mollo S, Armienti P, Ubide T, Nazzari M, Scarlato $\mathrm{P}$ (2020) The role of undercooling during clinopyroxene growth in trachybasaltic magmas: insights on magma decompression and cooling at Mt. Etna volcano. Geochim Cosmochim Acta 268:258-276. https://doi.org/10.1016/j.gca.2019.10.009

Melnik OE, Blundy JD, Rust AC, Muir DD (2011) Subvolcanic plumbing systems imaged through crystal size distributions. Geology 39:403-406. https://doi.org/10.1130/G31691.1

Meyer FJ, McAlpin DB, Gong W, Ajadi O, Arko S, Webley PW, Dehn J (2015) Integrating SAR and derived products into operational volcano monitoring and decision support systems. ISPRS J Photogramm Remote Sens 100:106-117. https://doi.org/10.1016/j. isprsjprs.2014.05.009

Moebis A, Cronin SJ, Neall VE, Smith IE (2011) Unravelling a complex volcanic history from fine-grained, intricate Holocene ash sequences at the Tongariro Volcanic Centre, New Zealand. Quatern Int 246(1-2):352-363. https://doi.org/10.1016/j.quaint.2011. 05.035

Mollo S, Del Claudio P, Ventura G, Iezzi G, Scarlato P (2010) Dependence of clinopyroxene composition on cooling rate in basaltic magmas: implications for thermobarometry. Lithos $118(3-$ 4):302-312. https://doi.org/10.1016/j.lithos.2010.05.006

Mollo S, Lanzafame G, Masotta M, Iezzi G, Ferlito C, Scarlato P (2011a) Cooling history of a dike as revealed by mineral chemistry: a case study from Mt. Etna volcano. Chem Geol 288(1):3952. https://doi.org/10.1016/j.chemgeo.2011.06.016

Mollo S, Putirka K, Iezzi G, Del Gaudio P, Scarlato P (2011b) Plagioclase-melt (dis)equilibrium due to cooling dynamics: implications for thermometry, barometry and hygrometry. Lithos 125(1):221-235. https://doi.org/10.1016/j.lithos.2011.02.008

Morimoto N (1989) Nomenclature of pyroxenes. Mineral J 14(5):198_ 221. https://doi.org/10.2465/minerj. 14.198

Mortimer N (2004) New Zealand's geological foundations. Gondwana Res 7(1):261-272. https://doi.org/10.1016/S1342-937X(05) 70324-5

Moschini P, Mollo S, Gaeta M, Fanara S, Nazzari M, Petrone CM, Scarlato P (2021) Parameterization of clinopyroxene growth kinetics via crystal size distribution (CSD) analysis: insights into the temporal scales of magma dynamics at Mt. Etna volcano. Lithos. https://doi.org/10.1016/j.lithos.2021.106225

Mujin M, Nakamura M, Miyake A (2017) Eruption style and crystal size distributions: crystallization of groundmass nanolites in the 2011 Shinmoedake eruption. Am Mineral 102:2367-2380. https://doi.org/10.2138/am-2017-6052CCBYNCND

Muncill GE, Lasaga AC (1988) Crystal-growth kinetics of plagioclase in igneous systems: isothermal $\mathrm{H}$ sub $2 \mathrm{O}$-saturated experiments and extension of a growth model to complex silicate melts. Am Mineral 73:982-992

Murphy MD, Sparks RSJ, Barclay J, Carroll MR, Brewer TS (2000) Remobilization of andesite magma by intrusion of mafic magma at the Soufriere Hills volcano, Montserrat, West Indies. J Petrol 41:21-42. https://doi.org/10.1093/petrology/41.1.21

Nakagawa M, Wada K, Thordarson T, Wood CP, Gamble JA (1999) Petrologic investigations of the 1995 and 1996 eruptions of Ruapehu volcano, New Zealand: formation of discrete and small magma pockets and their intermittent discharge. Bull Volcanol 61(1-2):15-31. https://doi.org/10.1007/s004450050259

Nakamura Y (1973) Origin of sector-zoning of igneous clinopyroxenes. Am Mineral 58(11-12):986-990

Nakamura M (1995) Continuous mixing of crystal mush and replenished magma in the ongoing Unzen eruption. Geology 23(9):807-810. https://doi.org/10.1130/0091-7613(1995)023\% 3C0807:CMOCMA\%3E2.3.CO;2

Nakao S, Morita Y, Oikawa J, Ueda H, Takahashi H, Ohta Y, Matsushima T, Iguchi M (2013) Volume change of the magma reservoir relating to the 2011 Kirishima Shinmoe-dake eruption-charging, discharging and recharging process inferred from GPS 
measurements. Earth Planets Space 65(3):505-515. https://doi. org/10.5047/eps.2013.05.017

Nelson ST, Montana A (1992) Sieve-textured plagioclase in volcanic rocks produced by rapid decompression. Am Mineral 77:1242-1249

Noguchi S, Toramaru A, Shimano T (2006) Crystallization of microlites and degassing during magma ascent: constraints on the fluid mechanical behavior of magma during the Tenjo eruption on Kozu Island, Japan. Bull Volcanol 68(5):432-449. https://doi. org/10.1007/s00445-005-0019-4

Pankhurst MJ, Morgan D, Thordarson T, Loughlin SC (2018) Magmatic crystal records in time, space, and process, causatively linked with volcanic unrest. Earth Planet Sci Lett 493:231-241. https://doi.org/10.1016/j.eps1.2018.04.025

Pansino S, Emadzadeh A, Taisne B (2019) Dike channelization and solidification: time scale controls on the geometry and placement of magma migration pathways. J Geophys Res Solid Earth 124(9):9580-9599. https://doi.org/10.1029/2019JB018191

Pardo N, Cronin SJ, Wright HMN, Schipper C, Smith I, Stewart B (2014) Pyroclast textural variation as an indicator of eruption column steadiness in andseitic Plinian eruptions at Mt. Ruapehu. Bull Volcanol. https://doi.org/10.1007/s00445-014-0822-x

Price GD, Gamble JA, Smith IEM, Stewart RB, Eggins S, Wright IC (2005) An integrated model for the temporal evolution of andesites and rhyolites and crustal development in New Zealand's North Island. J Volcanol Geoth Res 140:1-24. https://doi. org/10.1016/j.jvolgeores.2004.07.013

Putirka KD (2008) Thermometers and barometers for volcanic systems. Rev Mineral Geochem. https://doi.org/10.2138/rmg.2008.69.3

Renjith ML (2014) Micro-textures in plagioclase from 1994-1995 eruption, Barren Island volcano: evidence of dynamic magma plumbing system in the Andaman subduction zone. Geosci Front 5(1):113-126. https://doi.org/10.1016/j.gsf.2013.03.006

Sakuyama M (1984) Magma mixing and magma plumbing systems in island arcs. Bull Volcanol 47:685-703. https://doi.org/10.1007/ BF01952339

Schleider JM, Bergantz GW, Breidenthal RE, Burgisser A (2016) Time scales of crystal mixing in magma mushes. Geophys Res Lett 43(4):1543-1550. https://doi.org/10.1002/2015GL067372

Shane P, Doyle LR, Nairn IA (2007) Heterogeneous andesite-dacite ejecta in 26-16.6 ka pyroclastic deposits of Tongariro volcano New Zealand: the product of multiple magma-mixing events. Bull Volcanol 70(4):517-536. https://doi.org/10.1007/ s00445-007-0152-3

Shane P, Maas R, Lindsay JM (2017) History of Red Crater volcano, Tongariro volcanic centre (New Zealand): abrupt shift in magmatism following recharge and contrasting evolution between neighboring volcanoes. J Volcanol Geoth Res 340:1-15. https:// doi.org/10.1016/j.jvolgeores.2017.04.008

Shane P, Cocker K, Coote A, Stirling CH, Reid MR (2019) The prevalence of plagioclase antecrysts and xenocrysts in andesite magma, exemplified by lavas of the Tongariro volcanic complex, New Zealand. Contrib Mineral Petrol. https://doi.org/10.1007/ s00410-019-1626-y

Sharp TG, Stevenson RJ, Dingwell DB (1996) Microlites and "nanolites" in rhyolitic glass: microstructural and chemical characterization. Bull Volcanol 57(8):631-640. https://doi.org/10.1007/ s004450050116

Solaro C, Martel C, Champallier R, Boudon G, Balcone-Boissard H, Pichavant M (2019) Petrological and experimental constraints on magma storage for large pumiceous eruptions in Dominica island (Lesser Antilles). Bull Volcanol. https://doi.org/10.1007/ s00445-019-1313-x

Sosa-Ceballos G, Gardner JE, Lassiter JC (2014) Intermittent mixing processes occurring before Plinian eruptions of Popocatepetl volcano, Mexico: insights from textural-compositional variations in plagioclase and $\mathrm{Sr}-\mathrm{Nd}-\mathrm{Pb}$ isotopes. Contrib Mineral Petrol 167:966. https://doi.org/10.1007/s00410-014-0966-

Sparks RSJ (1978) The dynamics of bubble formation and growth in magmas: a review and analysis. J Volcanol Geoth Res 3:1-37. https://doi.org/10.1016/0377-0273(78)90002-1

Sparks RSJ, Sigurdsson H, Wilson L (1977) Magma mixing: a mechanism for triggering acid explosive eruptions. Nature 267:315318. https://doi.org/10.1038/267315a0

Streck MJ (2008) Mineral textures and zoning as evidence for open system processes. Rev Mineral Geochem 69(1):595-622. https:// doi.org/10.2138/rmg.2008.69.15

Szramek L, Gardner JE, Larsen J (2006) Degassing and microlite crystallization of basaltic andesite magma erupting at Arenal volcano, Costa Rica. J Volcanol Geoth Res 157:182-201. https:// doi.org/10.1016/j.jvolgeores.2006.03.039

Taddeucci J, Cimarelli C, Alatorre-Ibargüengoitia MA, Delgado-Granados H, Andronico D, Del Bello E, Scarlato P, Di Stefano F (2021) Fracturing and healing of basaltic magmas during explosive volcanic eruptions. Nat Geosci 14(4):248-254. https://doi. org/10.1038/s41561-021-00708-1

Taisne B, Jaupart C (2011) Magma expansion and fragmentation in a propagating dyke. Earth Planet Sci Lett 301:146-152. https://doi. org/10.1016/j.epsl.2010.10.038

Tost M, Price GD, Cronin SJ, Smith IEM (2016) New insights into the evolution of the magmatic system of a composite andesite volcano revealed by clasts from distal mass-flow deposits: Ruapehu volcano, New Zealand. Bull Volcanol. https://doi.org/10.1007/ s00445-016-1030-7

Turner SP, George RMM, Jerram DA, Carpenter N, Hawkesworth CJ (2003) Case studies of plagioclase growth and residence times in island arc lavas from Tonga and the Lesser Antilles, and a model to reconcile discordant age information. Earth Planet Sci Lett 214:279-294. https://doi.org/10.1016/S0012-821X(03)00376-5

Ubide T, Kamber BS (2018) Volcanic crystals as time capsules of eruption history. Nat Commun. https://doi.org/10.1038/ s41467-017-02274-w

Ubide T, Caulfield J, Brandt C, Bussweiler Y, Mollo S, Di Stefano F, Nazzari M, Scarlato P (2019) Deep magma storage revealed by multi-method elemental mapping of clinopyroxene megacrysts at Stromboli volcano. Front Earth Sci. https://doi.org/10.3389/ feart.2019.00239

Ubide T, Mollo S, Zhao J, Nazzari M, Scarlato P (2019b) Sector-zoned clinopyroxene as a recorder of magma history, eruption triggers, and ascent rates. Geochim Cosmochim Acta 251:265-283. https://doi.org/10.1016/j.gca.2019.02.021

Walker GPL, Skelhorn RR (1966) Some associations of acid and basic igneous rocks. Earth-Sci Rev 2:93-109. https://doi.org/10.1016/ 0012-8252(66)90024-9

Waters LE, Lange RA (2015) An updated calibration of the plagioclase-liquid hygrometer-thermometer applicable to basalts through rhyolites. Am Mineral 100(10):2172-2184. https://doi. org/10.2138/am-2015-5232

Weinberg RF (1996) Ascent mechanism of felsic magmas: news and views. Earth Environ Sci Trans R Soc Edinb 87(1-2):95-103. https://doi.org/10.1017/S0263593300006519

Welsch B, Faure F, Bachèlery P, Famin V (2009) Microcrysts record transient convection at Piton de la Fournaise volcano (La Réunion Hotspot). J Petrol 50(12):2287-2305. https://doi.org/10.1093/ petrology/egp076

Wilson CK, Jones CH, Gilbert H (2003) Single-chamber silicic magma system inferred from shear wave discontinuities of the crust and uppermost mantle, Coso geothermal area, California. J Geophys Res Solid Earth. https://doi.org/10.1029/2002JB001798

Witt-Eickschen G, Seck HA (1991) Solubility of Ca and AI in orthopyroxene from spinel peridotite: an improved version of an empirical geothermometer. Contrib Mineral Petrol 106:431-439 
Yurimoto H, Nagashima K, Kunihiro T (2003) High precision isotope micro-imaging of materials. Appl Surf Sci 203-204:793. https:// doi.org/10.1016/S0169-4332(02)00825-5

Zellmer GF (2021) Gaining acuity on crystal terminology in volcanic rocks. Bull Volcanol. https//doi.org/10.1007/ s00445-021-01505-9

Zellmer GF, Edmonds M, Straub SM (2015) Volatiles in subduction zone magmatism. In: Zellmer GF, Edmonds M, Straub SM (eds) The role of volatiles in the genesis evolution and eruption of arc magmas. Geological Society, London, pp 1-17 (Special Publications)

Zellmer GF, Sakamoto N, Hwang S-L, Matsuda N, lizuka Y, Moebis A, Yurimoto H (2016a) Inferring the effects of compositional boundary layers on crystal nucleation, growth textures, and mineral chemistry in natural volcanic tephras through submicronresolution imaging. Front Earth Sci 4:88. https://doi.org/10.3389/ feart.2016.00088

Zellmer GF, Sakamoto N, Matsuda N, Iizuka Y, Moebis A, Yurimoto H (2016b) On progress and rate of the peritectic reaction $\mathrm{Fo}+\mathrm{SiO}_{2}$ $\rightarrow$ En in natural andesitic arc magmas. Geochim Cosmochim Acta 185:383-393. https://doi.org/10.1016/j.gca.2016.01.005

Zellmer GF, Sakamoto N, Matsuda N, Iizuka Y, Moebis A, Yurimoto $\mathrm{H}$ (2018) Corrigendum to "on progress and rate of the peritectic reaction $\mathrm{Fo}+\mathrm{SiO}_{2} \rightarrow$ En in natural andesitic arc magmas." Geochim Cosmochim Acta 185:383-393. https://doi.org/10.1016/j. gca.2016.01.005

Zellmer GF, Iizuka Y, Lormand C (2020) Moebis A (2020) Beyond crystal mushes: evidence for uptake of high-T pyroxene antecrysts from mid- to upper crustal andesites into tephras from the Central Plateau New Zealand. NZ J Geol Geophys. https://doi. org/10.1080/00288306.2020.1848883

Publisher's Note Springer Nature remains neutral with regard to jurisdictional claims in published maps and institutional affiliations. 